\title{
norden
}

Norræna rádherranefndin

\section{Bjartari framtía}

13 alpjódasamningar um náttúru og menningarumhverfi

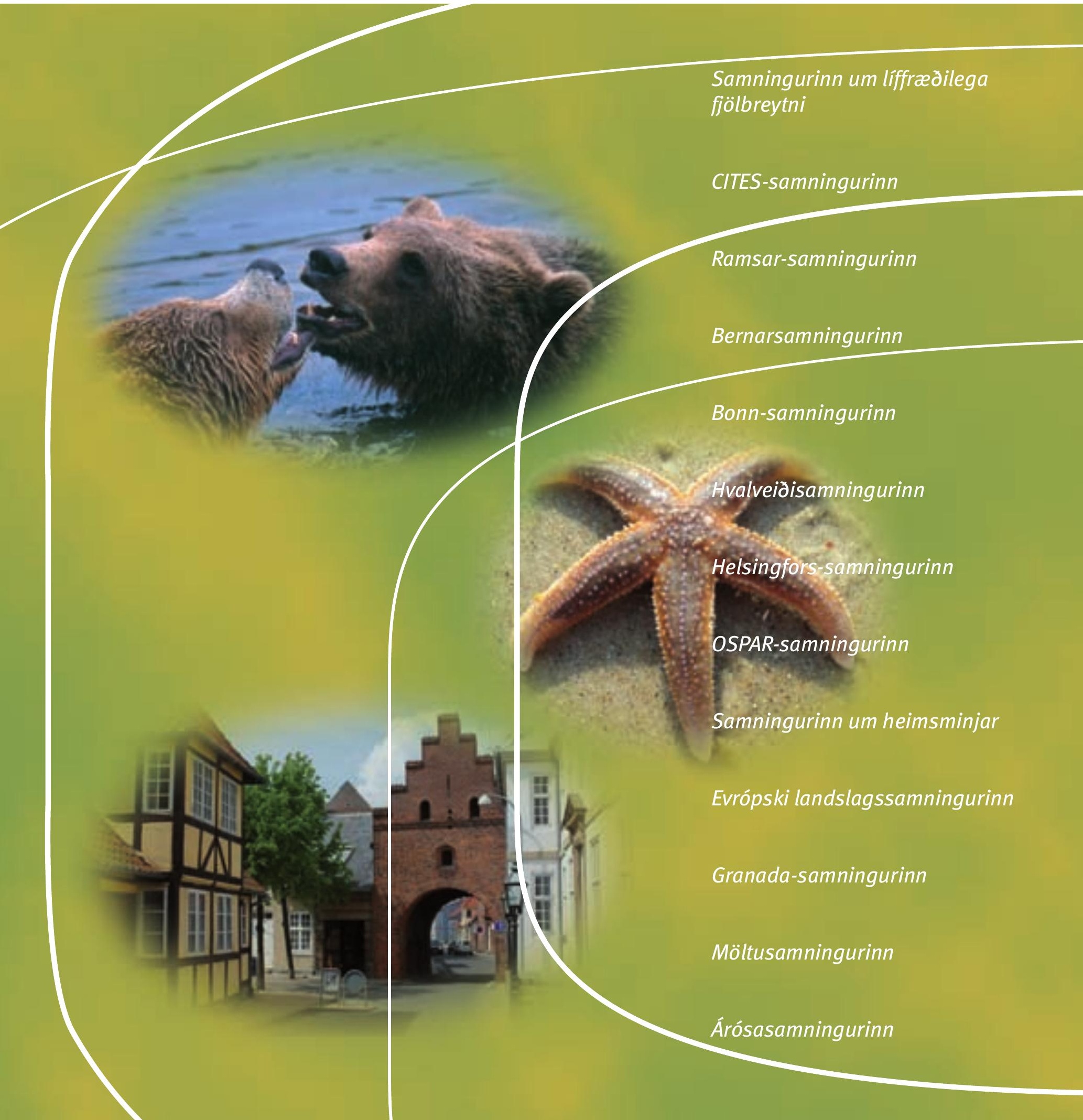




\section{Bjartari framtíd}

13 alpjódasamningar um náttúru og menningarumhverfi

\section{TemaNord 2006:563}




\section{Bjartari framtía}

13 alpjódasamningar um náttúru og menningarumhverfi

TemaNord 2006:563

(C) Nordisk Ministerråd, København 2006

ISBN 92-893-1376-5

Prentun: UniTryk

Umbrot og uppsetning: Naturplan (www.naturplan.dk)

Kápumynd: Mark Desholm/Naturplan, Inge-Marie Fruelund/Naturplan, Stig Bachmann Nielsen/Naturplan

Bakgrunnsmyndir: Kurt Petersen/Scanpix S. 10; Claro Cortes IV/Scanpix S. 14; Johnny Madsen/Scanpix S. 16;

Birthe Overgaard/Naturplan s. 18, 28; Klaus Mortensen/Naturplan s. 20; Jens Muff Hansen/Naturplan s. 24,

32; Inge-Marie Fruelund/Naturplan s. 26; Sven Halling/Scanpix s. 30; Grethe Bachmann/Naturplan s. 34; Stig

Bachmann Nielsen/Naturplan s. 36; Erik Smedegaard/Scanpix s. 38.

Upplag: 1500

Prentad á pappír sem uppfyllir strangar umhverfiskröfur og má merkja med svaninum, norræna umhverfismerkinu.

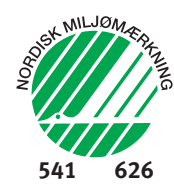

Ritið má panta á www.norden.org/order. Fleiri rit eru á www.norden.org/publikationer

Prentad í Danmörku

\section{Norræna ráðherranefndin}

Store Strandstræde 18

DK-1255 Kaupmannahöfn K

Sími (+45) 33960200

Bréfasími (+45) 33960202

\section{Norðurlandarád}

Store Strandstræde 18

DK-1255 Kaupmannahöfn K

Sími (+45) 33960400

Bréfasími (+45) 33111870

www.norden.org

\section{Norrænt samstarf}

Norrænt samstarf er eitt elsta og umsvifamesta svæðisbundna samstarf í heiminum. Aðilar að samstarfinu eru Danmörk, Finnland, Ísland, Noregur, Svípjód, Álandseyjar, Færeyjar og Grænland. Samstarfið eflir samkennd Norðurlandapjóda og

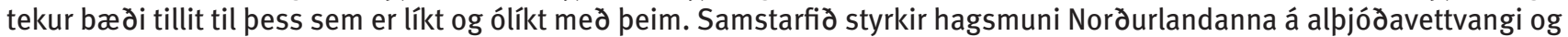
eflir gód samskipti nágrannapjódanna.

Samstarfinu var formlega komið á með stofnun Nordurlandaráds árið 1952 en pad er vettvangur pingmanna og ríkisstjórna norrænu ríkjanna. Árid 1962 undirrituðu norrænu ríkin Helsingfors-sáttmálann og er hann enn sá grundvöllur sem norrænt samstarf byggir á. 1971 var Norrænu rádherranefndinni komida át og er hún formlegur samstarfsvettvangur norrænu ríkisstjórnanna og leidtoga sjálfstjórnarsvædanna Álandseyja, Færeyja og Grænlands. 
Formáli 6

Bjartari framtíd $\quad 8$

Samningurinn um líffrædilega fjölbreytni 10

CITES-samningurinn 14

Ramsar-samningurinn 16

Bernarsamningurinn $\quad 18$

Bonn-samningurinn $\quad 20$

Hvalveidisamningurinn $\quad 24$

Helsingfors-samningurinn $\quad 26$

OSPAR-samningurinn $\quad 28$

Samningurinn um heimsminjar 30

Evrópski landslagssamningurinn 32

Granada-samningurinn $\quad 34$

Möltusamningurinn $\quad 36$

Árósasamningurinn $\quad 38$

Alpjódaskrifstofur $\quad 40$ 


\section{Formáli}

Norðurlöndin hafa tekið pátt í gerð fjölda alpjóðasamninga sem ætlað er að tryggja náttúru- og menningararfleifð heimsins.

Samningarnir stuðla að vernd náttúru sem er auðug að búsvæðum og tegundum lífvera. Náttúran á sér sinn rétt og hefur mikla pýdingu par sem hún styrkir félagslega og efnahagslega próun um allan heim. Auk pess er lítt snortin náttúra og ómengað umhverfi lykill að heilbrigði manna, velferð og lífsgæðum.

Aukin áhersla hefur verið lögðá mikilvægi pess að vernda menningararfleifð heimsins í alpjódasamningum, m.a. byggingar, sem vitna um sérstæða byggingarlist, staði með ríkulegum fornleifum og fornminjar eða svæði par sem enn finnst menningarumhverfi með vel varðveittum tengslum fortíðar og nútíðar. Menningararfleifðin miðlar okkur sögulegri vitund og er mikilvægur grunnur fyrir sjálfsmynd okkar - hvaðan sem við erum upprunnin í veröldinni.

Norðurlöndin leggja áherslu á vernd sameiginlegrar náttúru og menningararfleifðar. Alpjóðasamningarnir eru mikilvæg tæki í pessu starfi pví að mestur árangur næst með sameiginlegu átaki pvert á landamæri.

Í pessum bæklingi er stutt kynning á 13 mikilvægustu alpjódasamningunum á sviði náttúru og menningararfleifðar sem Norðurlöndin eiga aðild að og í mörgum tilvikum komu pau að gerð pessara samninga.

Pess er vænst að efni bæklingsins auki pekkingu manna á samningunum - p. á m. hjá stjórnmálamönnum, stjórnendum, kennurum og öðrum sem hafa áhuga á náttúru okkar og menningararfleifo.

Sameiginleg útgáfa bæklingsins er lýsandi fyrir langa hefə norræns samstarfs um málefni sem hafa alpjódlega pýðingu. Gott samstarf um samningana getur stuðlað að auknum áhrifum á heimsvísu - til ánægju bæði fyrir núlifandi kynslóðir og pær sem á eftir koma - jafnframt bví sem við styrkjum samheldni Norðurlandapjóðanna.

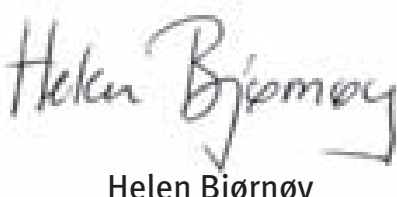

umhverfisrádherra

Noregs

fyrir hönd norrænu ráðherranefndarinnar,

ráðherrar sem bera ábyrgð á umhverfisvernd og varðveislu menningararfleifðar 


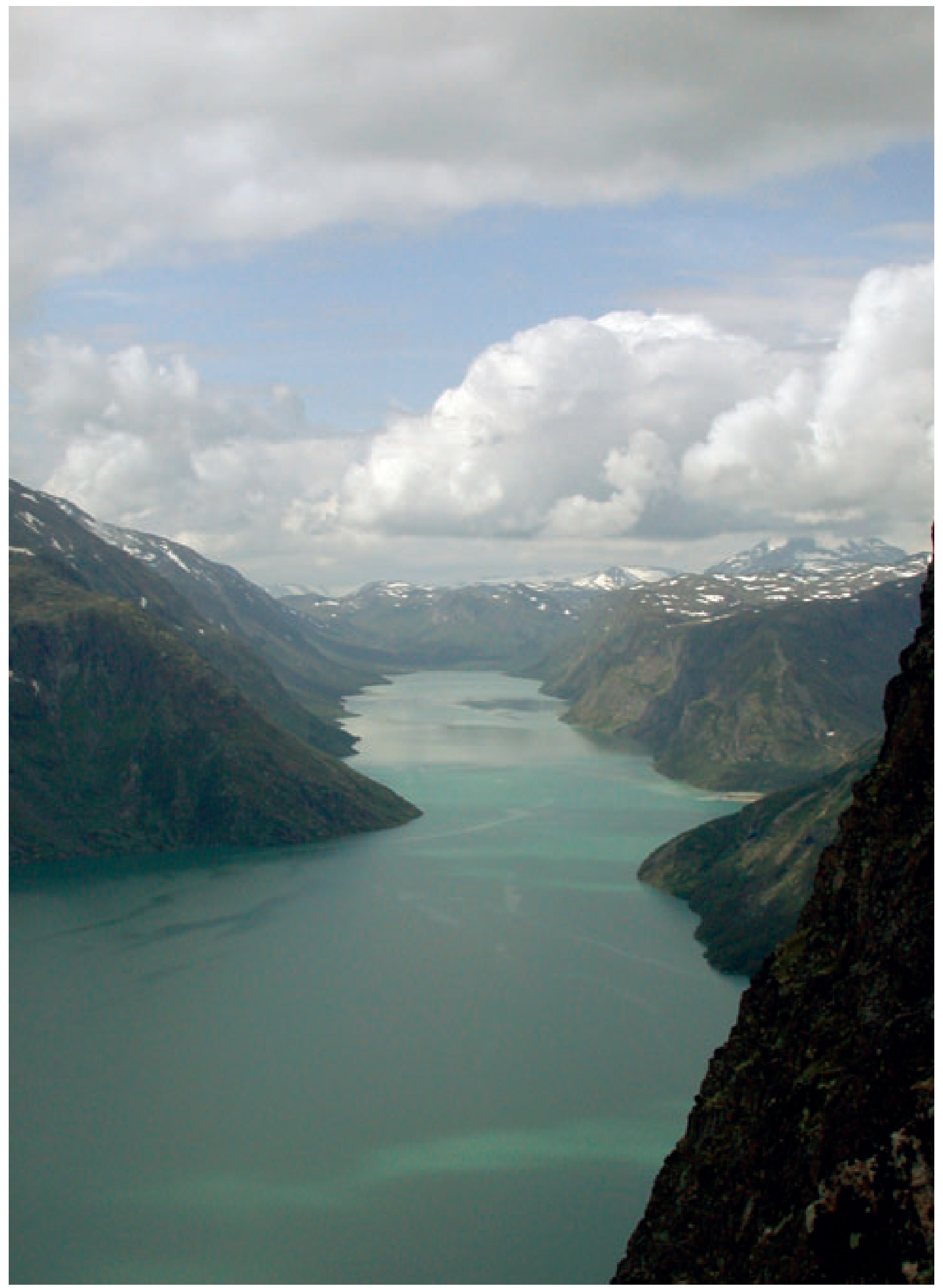

Gjende, í pjóðgarðinum i Jötunheimum, Noregi (ljósm.: Jens Muff Hansen/Naturplan) 


\section{Bjartari framtíd}

Á Norðurlöndunum búa menn að langri hefə̀ sem felst í að vernda náttúruna og menningarlegt umhverfi. Árum saman var vernd náttúru- og menningarminja málefni hvers ríkis um sig, en sídan hefur verndin fengið á sig æ alpjódlegri blæ.

\section{Alpjódasamtök}

Elstu, albjódlegu verndarsamtök heims voru sett á laggirnar árið 1922. Petta var Alpjódafuglaverndarrádið, ICBP, sem var undanfari BirdLife International. Árið 1948 voru Alpjódanáttúruverndarsamtökin, IUCN, stofnuð og alpjódlegt sam-

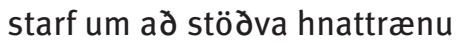
umhverfiskreppuna hófst fyrir alvöru. Frá pessum tíma hafa mörg samtök, bædi stór og smá, verið sett á laggirnar og pau hafa öll studlað að samkomulagi fjölda ríkja um à pau muni í sameiningu beita sér fyrir átaki í vernd náttúru- og menningarminja. Í mörgum tilvikum hefur petta orðið til pess að alpjódasamningar hafa verið gerðir.

\section{Eðli alpjódasamninga}

Alpjódasamningar eru bindandi pjódréttarsamningar milli ríkja eða alpjódlegra stofnana. Margir samningar taka til alls heimsins, en aðrir eru takmarkaðri - ná til dæmis til Evrópu eda hluta Evrópu. Aðildaríkin halda reglulega fundi par sem rætt er um pær skuldbindingar sem pau hafa tekið á sig með aðild að samningi. Par eru jafnframt ræddar breytingar á pví hvada tegundir plantna eəa dýra eəa hvaða svæði tiltekinn samningur skuli taka til.
13 alpjódasamningar - frá
sjónarhóli Norðurlandanna

Öll Norðurlöndin hafa gerst aðilar à samningum á svið̇i náttúru- og menningarminja. I pessum bæklingi eru 13 mikilvægustu samningarnir sem varða Norðurlöndin. Samningarnir eru sýndir í töflunni til hægri.

Í bæklingnum er gefið stutt yfirlit yfir samningana og vísad er til frekari heimilda um pá.

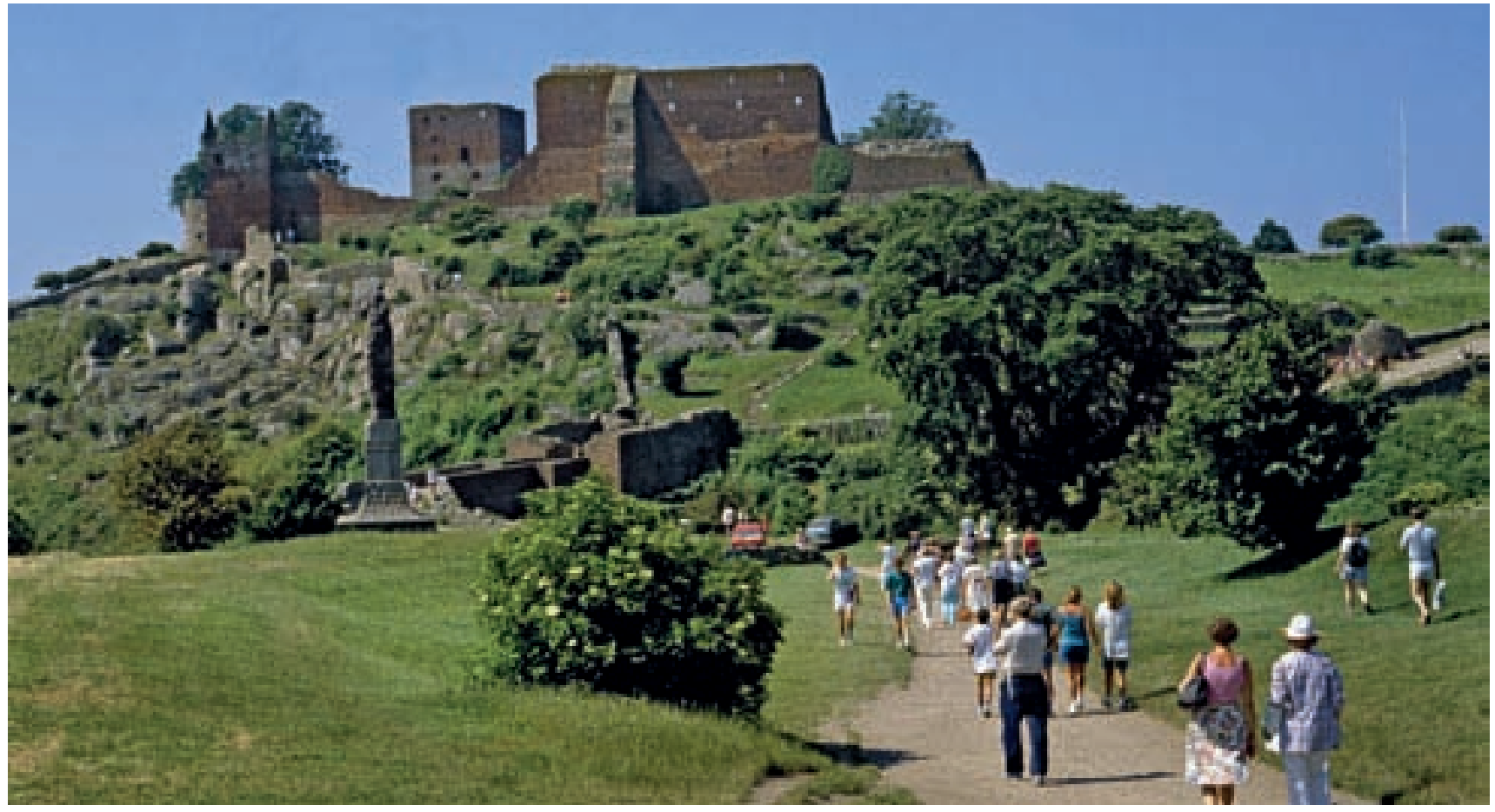




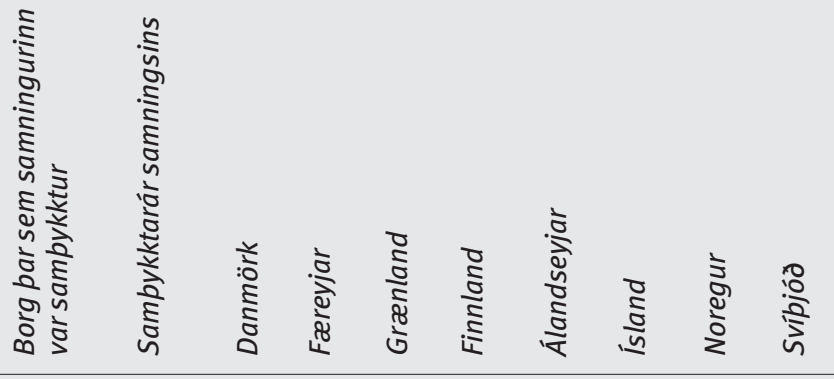

\section{Samningar um náttúruna}

Samningurinn um líffrædilega fjölbreytni

(The Convention on Biological Diversity)

CITES-samningurinn

(The Convention on International Trade in Endangered Species of Wild Fauna and Flora)

Ramsar-samningurinn

(Convention on Wetlands)

Bernarsamningurinn

(The Convention on the conservation of European Wildlife and Natural Habitats)

Bonn-samningurinn

(Convention on Migratory Species of Wild Animals)

Hvalveiðisamningurinn

(International Convention for the Regulation of Whaling)

\section{Svæəisbundnir samningar um hafsvæəi}

Helsingfors-samningurinn

(Convention on the Protection of the Marine Environment of the

Baltic Sea Area)

OSPAR-samningurinn

(Convention for the protection of the marine environment of the North-east Atlantic)

\section{Samningar um menningu og landslag}

Samningurinn um heimsminjar

(Convention Concerning the Protection Of The Cultural and Natural Heritage)

Evrópski landslagssamningurinn

(The European Landscape Convention)

Granada-samningurinn

(Convention for the Protection of Architectural Heritage in Europe)

Möltusamningurinn

(Convention on the Projection of Archaeological Heritage in Europe)

\section{Samningar almenns eəlis}

Árósasamningurinn

(The Convention on Access to Information, Public Participation in Decision Making and Access to Justice in Environmental Matters)

Rio De Janeiro 1992

Washington

1973

Ramsar

1971

Bern

1979

Bonn

1979

Washington

1946

Helsinki

1992

Paris

1992

Paris

1972

Firenze

2000

Granada

1985

Valletta

199

1998

Merkingar:

+ Ríkið er bundið af samningnum

- Ríkid er óbundid af samningnum 


\section{Samningurinn um líffrædilega fjölbreytni}

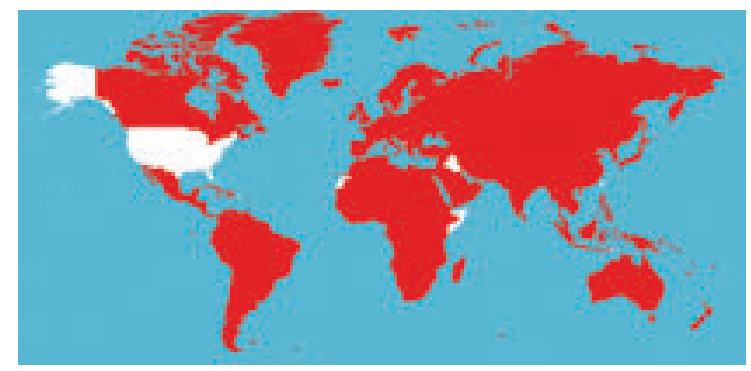

Samningurinn um líffræðilega fjölbreytni (CBD) var sampykktur á leiðtogafundi í Ríó de Janeiró ário 1992. Á leiðtogafundi i Jóhannesarborg 10 árum sídar staðfestu leiðtogar yfir 150 ríkja að samningurinn væri mikilvægasta tækið sem pjódir heims byggju yfir til pess að tryggja líffræðilega fjölbreytni.

Samningurinn kom til vegna áhyggna pjóda heims yfir pví hve mikið glatast af líffræðilegri fjölbreytni. Hann undirstrikar nauðsyn pess að sporna gegn pessari skerðingu á líffræðilegri fjölbreytni með vernd og sjálfbærri próun.

Nú hafa 188 lönd gerst aðilar að samningnum, m.a. öll Norðurlöndin.

\section{Hvað er átt við með líffrædilegri fjölbreytni?} Með líffræðilegri fjölbreytni er átt við tegundaauðgi plantna, dýra og örvera og fjölbreytileika peirrar náttúru sem lífverurnar eru hluti af. Einnig telst erfðabreytileiki innan tegundanna hluti líffræðlegrar fjölbreytni, til dæmis sá erfðabreytileiki sem greina má hjá stofnum tiltekinna tegunda sem lifa á víðáttumiklu svæði. Pessi líffræðilega fjölbreytni hefur orðið til við ármilljóna próun.

\section{Markmiðið með samningnum}

Markmiðið með samningnum um líffræðilega fjölbreytni er að vernda líffræðilega fjölbreytni, tryggja sjálfbæra nýtingu líffræðilegra audlinda, svo og að tryggja að arðurinn af nýtingu erfðaauðlinda skiptist sanngjarnt milli landanna.

Púsaldarvistmat Sameinuðu pjódanna frá árinu 2005 (Millennium Ecosystem Assessment) leiðir í ljós à madurinn hefur á sídustu 50 árum valdið meiri breytingum á náttúrunni en á nokkru öəru tímabili í sögu mannkyns. Um 50-100 sinnum fleiri tegundir verða nú aldauða á ári hverju en áður gerðist. Meðal helstu orsaka pessa eru glötun búsvæða, innflutningur nýrra tegunda, ofnýting, loftslagsbreytingar og mengun. Petta hefur áhrif á pad hvada kostir standa nú til boda. Vistmat Sameinuðu pjódanna undirstrikar jafnframt hversu mikid maðurinn á undir líffræðilegri fjölbreytni að pví er varðar pad að komast af og við sköpun verðmæta og hve mikilvæg hún er fyrir velferð og hagsæld okkar.

Erfðafræðileg fjölbreytni er mest i próunarlöndunum en iðnvæddu löndin búa hins vegar yfir peirri tækni sem parf til að̀ nýta auðlindirnar í viðskiptaskyni. Samningurinn studlar að próun sem tryggir réttláta skiptingu gæðanna.

\section{Árið 2010}

Á rádstefnu leiðtoga heims árið 2002 ákvádu ríkin ad freista pess à draga fyrir árið 2010 úr peirri skerðingu á líffræðilegri fjölbreytni sem leiðir af starfsemi mannsins. Á fundi evrópskra umhverfisrádherra i Kænugarði árið 2003 urðu rádherrarnir sammála um ad setja metnaðarfyllri markmið að pví er Evrópu varðar. Pað markmið var sett að freista pess að stöðva fyrir árið 2010 alla skerðingu á líffræðilegri fjölbreytni. Pessu skal nád meðal annars með pví að stofna vistfræðilegt net verndarsvæða með ósnortinni náttúru.

\section{Framkvæmd samningsins}

Aðildarlöndin skulu koma í kring innlendum áætlunum og aðgerðaáætlunum til að tryggja 


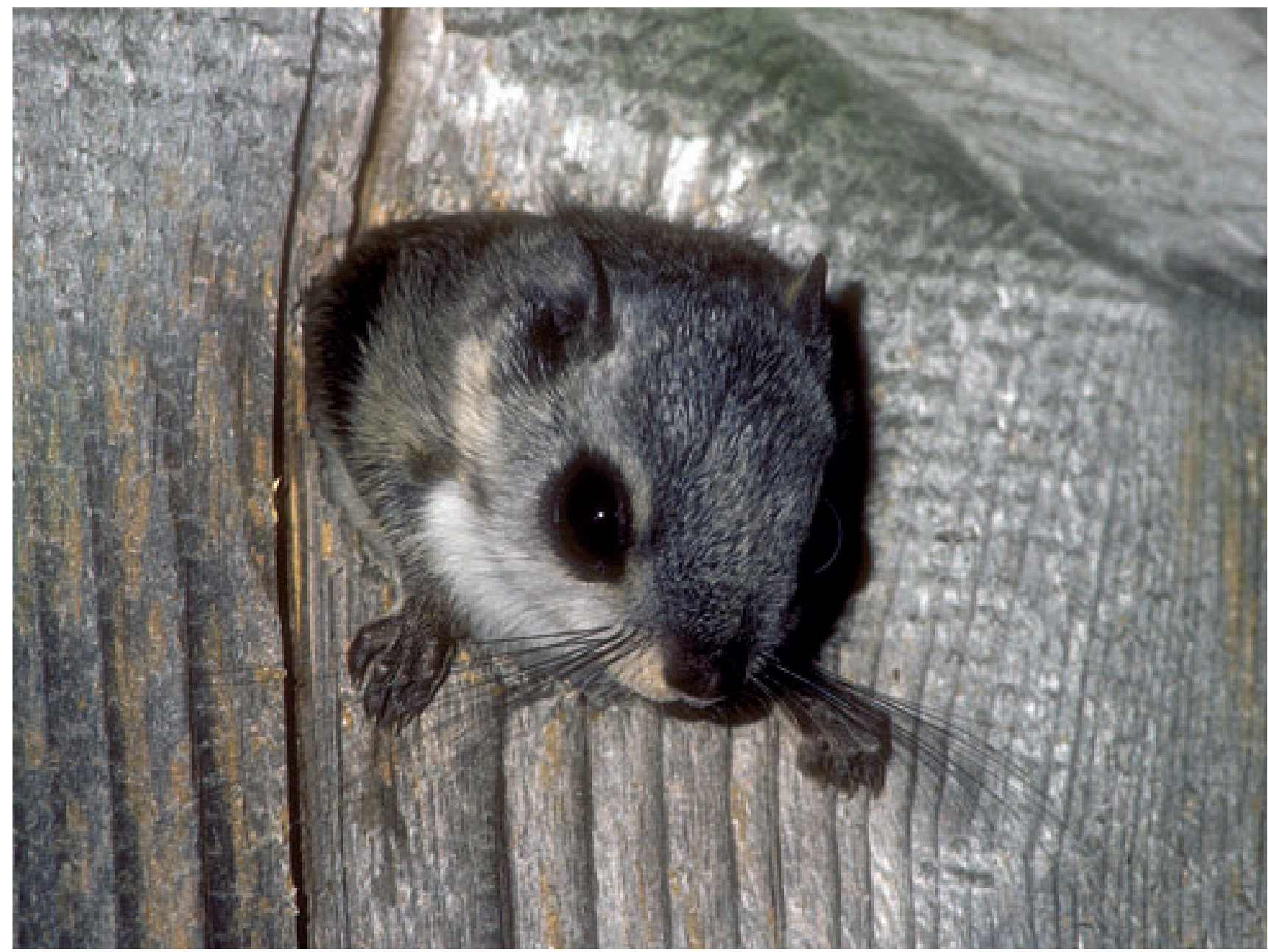

Á Norðurlöndunum lifir flugíkorninn (Pteromys volans) aðeins í Finnlandi. Tegundinni hefur hnignað en hún var áðu útbreidd um mest allt landið en á sér nú útbreiðslusvæði aðeins i suður og mið Finnlandi. Talið er að aukin skógrækt sé ástæðan fyrir pessari afturför (ljósm.: Jussi Murtosaari).

líffræðilega fjölbreytni - með samstarfi milli landa og óhád efnahagslegum mörkum.

Auðugu ríkin bera einnig ábyrgðá að stuðlað verði að pví, með aðstoð i umhverfismálum, à fátæk ríki verði fær um að hrinda samningnum î framkvæmd.

Unnið verður að frekari próun samningsins med pví að koma á fót starfsáætlunum, með stefnumörkun og bókunum sem eru lagalega bindandi.

İ samningnum er gengið út frá pví að madurinn er hluti náttúrunnar og að við verðum að nýta okkur audlindir hennar en jafnframt er

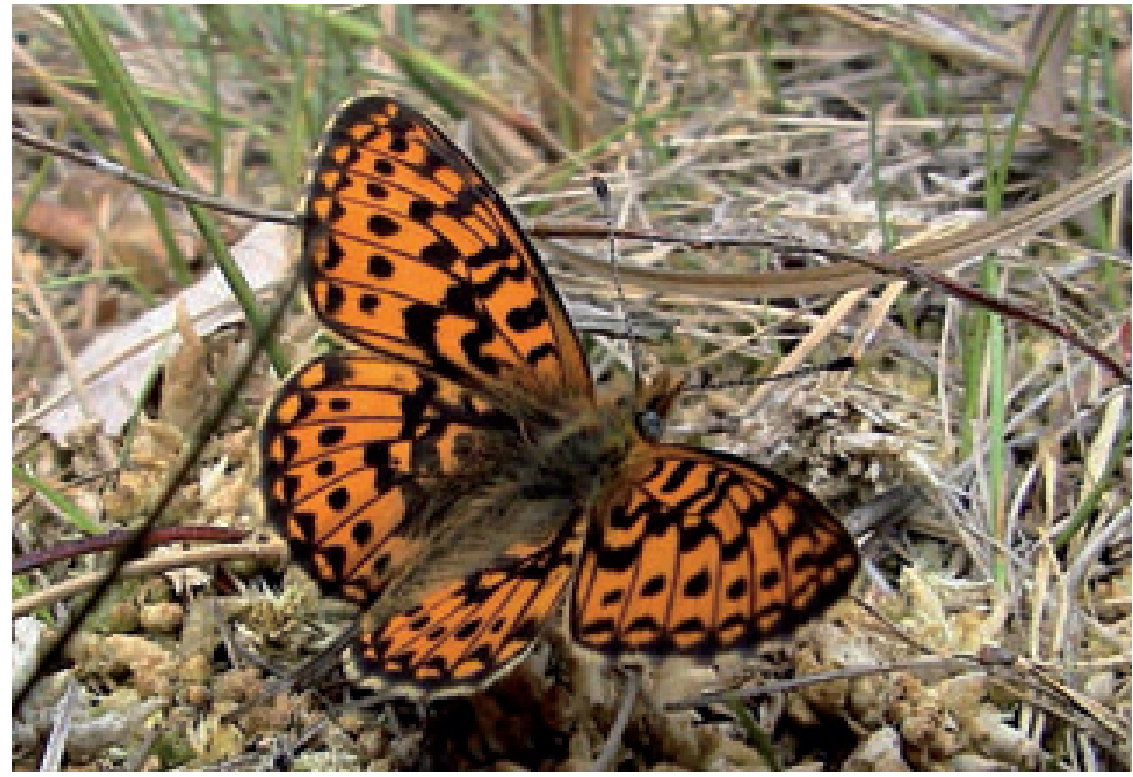

Sum skordýr eru hád tilteknum plöntum. Petta fiðrildi er af tegundinni Boloria aquilonaris og lirfa pess lifir á mýraberjum. Hverfi mosarnir par sem mýraberjalyngið vex er lífsgrundvellinum kippt undan pessari fiðrildategund (ljósm.: Andis Liepa/Naturplan). 


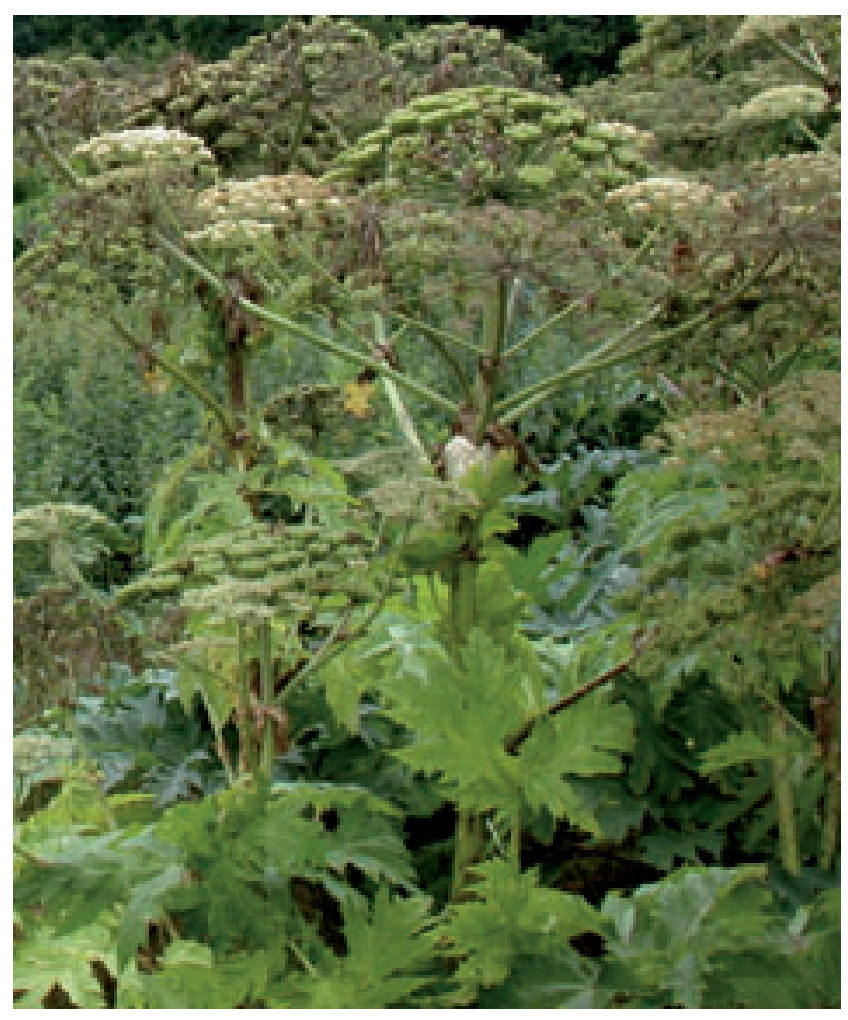

Samstarfi Norðurlandanna og Eystrasaltslandanna, NOBANIS, var komið á fót með pað að markmiði að hindra útbreiðslu ágengra tegunda á bord við tröllahvönn (Heracleum mantegazzianum) (ljósm.: Jens Muff Hansen/Naturplan).

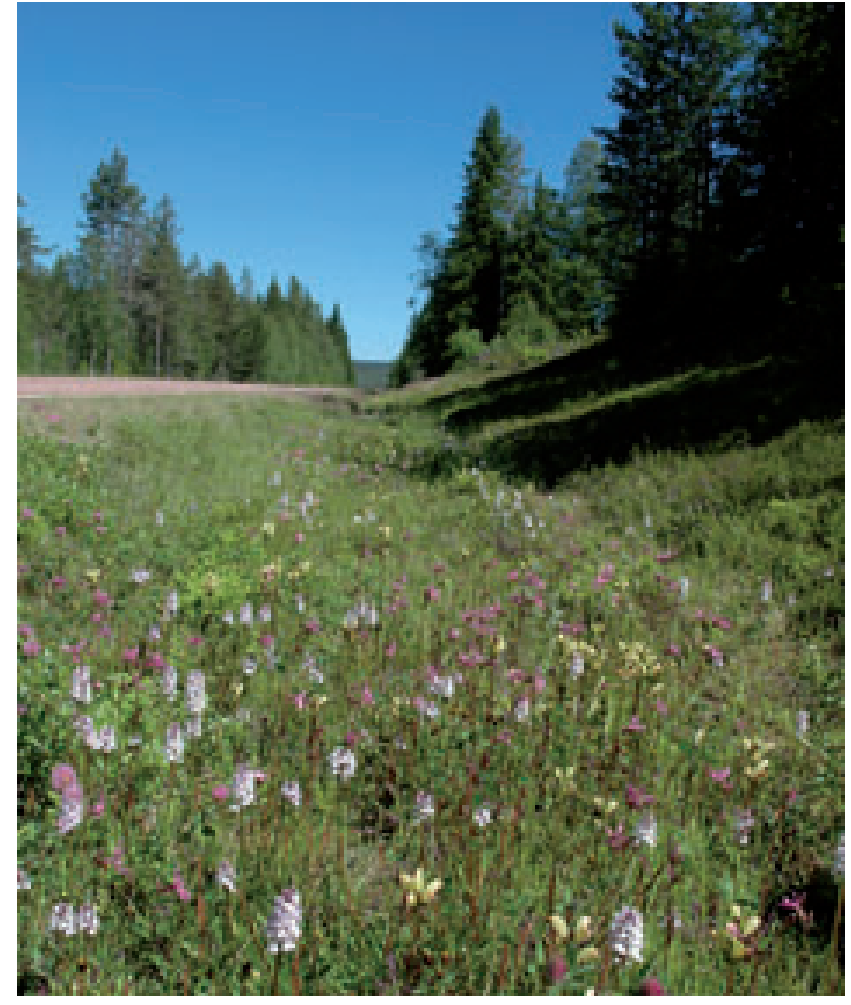

Fjölbreytt landslag með mörgum vistgerðum skapar lífsskilyrði fyrir fjölmargar tegundir liffvera (Indlandsvägen, Svípjód) (ljósm.: Carsten Brandt) okkur skylt að huga að pví hvaða áhrif pað hefur á vistkerfin.

\section{Fræðsla og skilningur}

Mikilvægt er ad sem flestir átti sig á peirri nauðsyn að varðveita líffræðilega fjölbreytni. Með fullgildingu samningsins hafa adildarríkin tekið á sig pá ábyrgð að upplýsa pegna sína um mikilvægi tegunda og búsvæða.

\section{Erfðaauðlindir}

Í samningnum er tryggt aə hvert ríki hefur óskoradan rétt til að nýta eigin audlindir.

Erfðaauðlindir hafa mikla efnahagslega pýðingu par eə pær eru hráefni meðal annars í tengslum við líftækni, gerə lyfja og snyrtivara, ræktun og kynbætur.

Áætlað er að um pað bil $40 \%$ af hagkerfi heimsins byggist á afurðum úr lífríkinu og líffræðilegum ferlum. Mikil umræða stendur nú um allan heim um hvernig haga skuli eignarrétti i tengslum við notkun erfðaauðlinda. Rök iðnaðarins fyrir notkun einkaleyfa eru pau ad rannsóknir á erfðaaudlindum séu nauðsynlegar fyrir próun nýrra lyfja og við próun matvæla og landbúnaðar, svo að dæmi séu tekin, og að slíkt gagnist öllu mannkyni. Ókostirnir við einkaleyfi eru peir að pau geta leitt til pess að erfaaaudlindir standi peim einum til boða sem hafa rád á greiða fyrir leyfin.

\section{Frumbyggjar og hefəbundnir lifnaðarhættir}

Samningurinn um líffræðilega fjölbreytni gerir rád fyrir sérstakri starfsáætlun fyrir frumbyggja og staðbundin samfélög par sem lifnaðarhættir byggjast á erfðavenjum.

\section{Norrænt samstarf}

Norðurlöndin hafa í sameiningu - á vegum Norræna rádherrarádsins - sett fram áætlun um nýtingu erfðaauðlinda. Markmiðið með norræna samstarfinu er að styrkja starf sem miðar að varðveislu erfðafjölbreytni og sjálfbærri nýtingu i landbúnaði og skógrækt, fiskveiðum og í tengslum við matvæli. Samstarfinu er einnig ætlað að stuðla að pví að markmið samningsins náist um aðgang að erfəaauðlindum og rétti par að lútandi.

Pá hefur verið komið á fót samstarfi Norðurlandanna og Eystrasaltsríkjanna um framandi og ásæknar tegundir (NOBANIS).

\section{Cartagena-bókunin}

Í janúar 2000 gerðu aðildarlöndin með sér viðbótarsamkomulag, 
Cartagena-bókunina, sem fjallar um próun erfðabreyttra lífvera. Samningnum er ætlað að tryggja að nægilegrar umhverfisverndar sé gætt pegar erfðabreyttar lífverur eru fluttar milli landa og við notkun peirra.

Norðurlöndin hafa öll skrifað undir Cartagena-bókunina. Undirritum Danmerkur tekur hvorki til Færeyja né Grænlands.

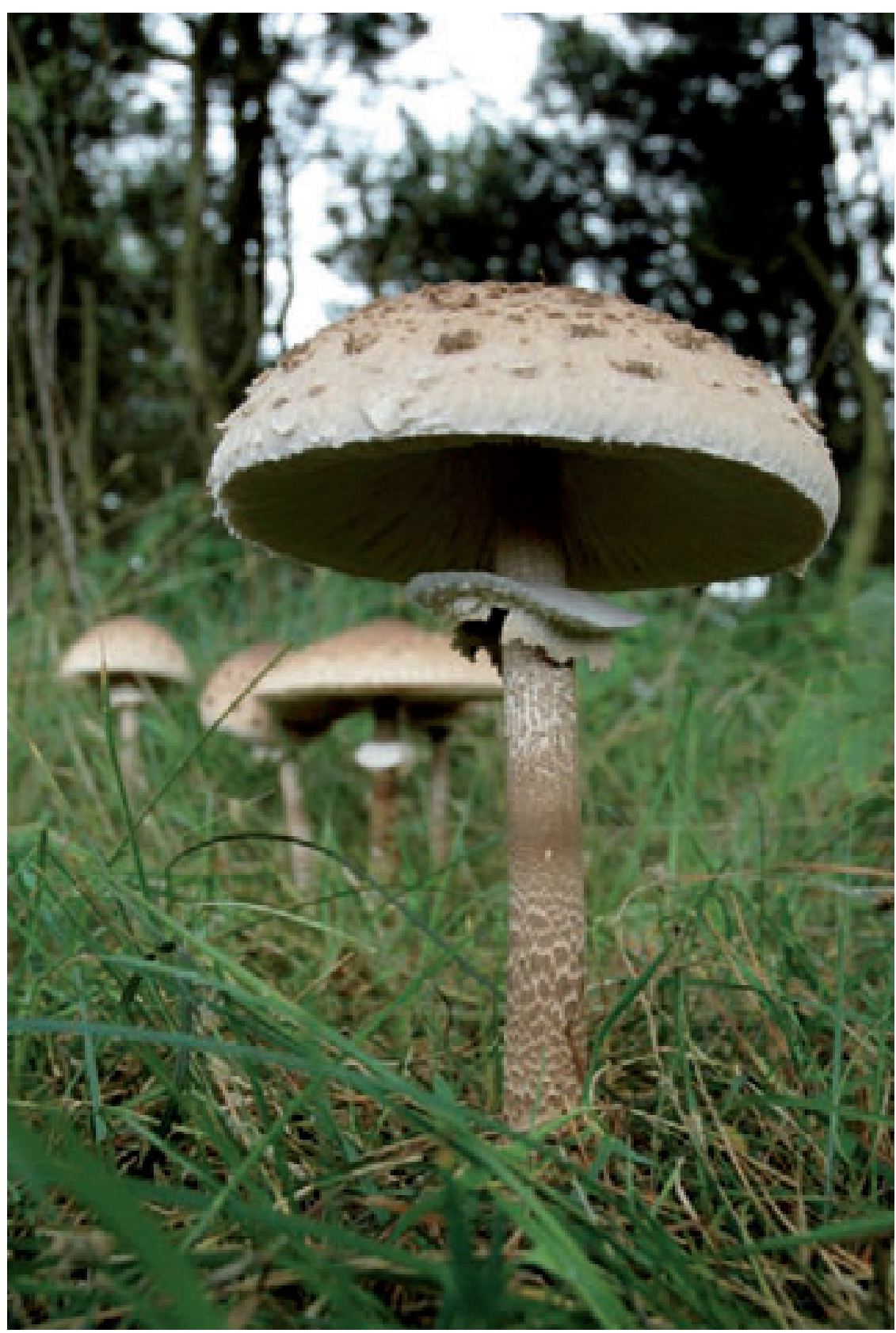

Líffræðileg fjölbreytni nær til allra hópa lífvera og búsvæða peirra (ljósm.: Carsten Brandt). 


\title{
CITES-samningurinn
}

\section{Samningurinn um alpjódaverslun med tegundir villtra}

\author{
dýra og plantna í útrýmingarhættu
}

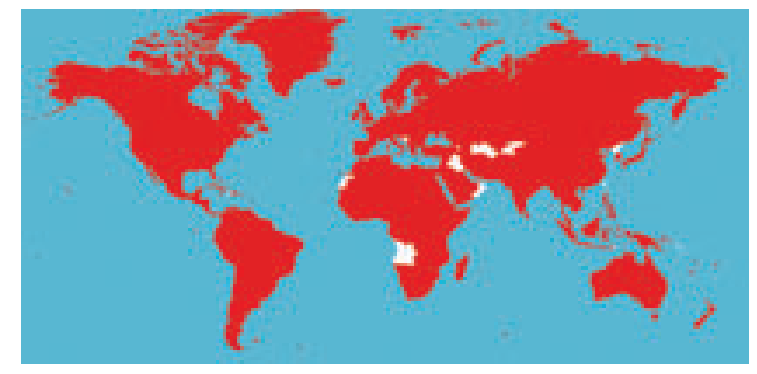

Veiðar villtra dýra í náttúrunni í peim tilgangi að halda peim föngnum eða nýta afurðir af peim er talin ein af ástæðunum fyrir pví að margar tegundir eru nú í útrýmingarhættu. Á sama hátt er mörgum tegundum plantna stefnt í hættu vegna pess að pær eru grafnar upp eða felldar. Víðtæk, alpjóðleg viðskipti eiga sér stað med margar af pessum tegundum, sem eru í hættu, og pau urðu til pess að CITES-samningurinn var sampykktur árið 1873 (Washingtonsamningurinn).

\section{Markmid}

Markmiðið með samningnum er aə vernda tegundir sem er ógnad vegna albjódlegra viðskipta.

Markmiðið er að viðskiptin skuli vera sjálfbær, p.e. ad ekki sé tekið meira af stofnunum en peir geta staðið undir.

Ákvæði samningsins gilda bæði um lifandi dýr eða plöntur og um afurðir af peim um pad bil 5000 dýrategundum og 28.000 plöntutegundum - par af eru hið minnsta 20.000 brönugrös - sem hafa verid sett á skrár samningsins (CITES-tegundir). Samningurinn tekur fyrst og fremst til hitabeltistegunda, en hann nær einnig til margra norrænna tegunda og í peim hópi eru m.a. uglur, ránfuglar, otur, úlfur og ísbjörn.

\section{Inntak samningsins}

Aðildarríkin skulu takmarka verslun með dýr og plöntur i útrýmingarhættu með pví aə banna inn- og útflutning ef pad er mat manna að viðskiptin muni auka hættuna á ad tegundunum verði útrýmt. Ef um er að ræða viðskipti meə tegundir sem eru ekki í mikilli útrýmingarhættu er unnt að sækja um sérstakt leyfi til inn- og útflutnings.

Tegundirnar, sem CITES-samningurinn tekur til, eru tilgreindar í premur skrám eftir pvi í hve mikilli útrýmingarhættu pær eru (1. rammi).

Rúmlega 1000 tegundir eru í svo mikilli útrýmingarhættu að verslun með pær er algerlega bönnuð (skrá I). Fyrir hinar tegundirnar er ávallt krafist sérstaks útflutningsleyfis (skrá II og III). Nokkur ríki setja auk pess pá kröfu að leyfi til innflutnings sé aflad.

\section{Sérstakar takmarkanir fyrir ríki Evrópusambandsins}

Evrópusambandið hefur sett strangari reglur fyrir inn- og útflutning peirra tegunda sem eru í útrýmingarhættu. Í sumum tilvikum gilda einnig sérstakar takmarkanir í tengslum við verslun innan Evrópusambandsríkjanna. Pær tegundir, sem falla undir ákvæði Evrópusambandsins, eru tilgreindar í 4. viðauka ESP tilskipunar við samninginn (2. rammi).
1. rammi:

Skrá I: Tegundir sem ekki má eiga viðskipti med. petta eru pær tegundir sem eru taldar vera i mestri útrýmingarhættu.

Skrá II: Tegundir sem leyft er að̀ eiga viðskipti með, en stjórna skal inn- og útflutningi til pess ad tryggja framtíd peirra.

Skrá III: Tegundir sem leyft er að eiga viðskipti med, à pví tilskildu að pær séu frá tilteknum ríkjum. 


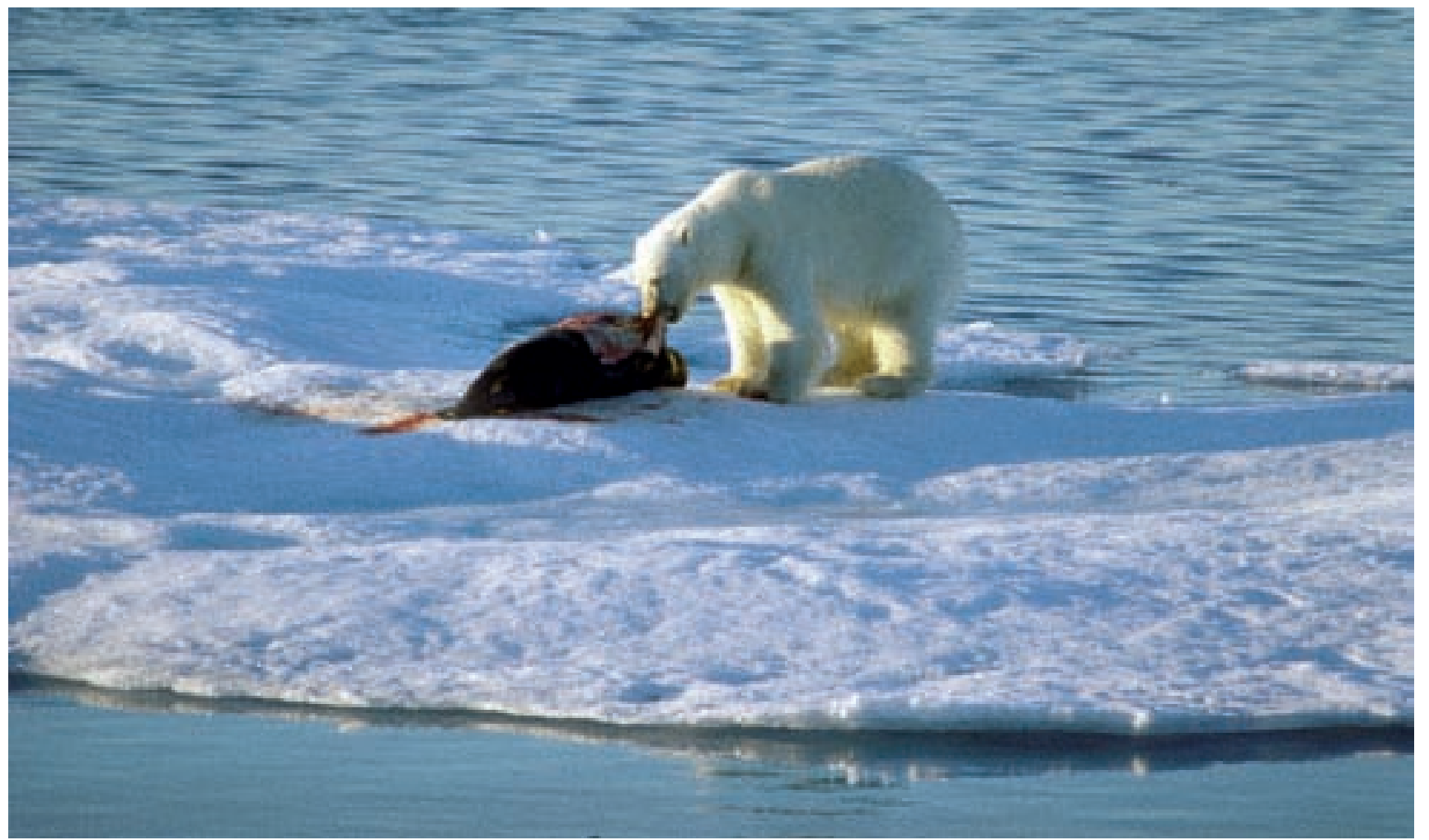

Hvítabjörninn er ein peirra norrænu tegunda sem CITES-samningurinn tekur til. Árum saman hafa menn veitt hvítabjörn (Ursus maritimus), meðal annars vegna eftirspurnar eftir feldinum (ljósm.: John Frikke).

\begin{abstract}
2. rammi:
Viðauki A: Tegundir í skrá l, ásamt tegundum í skrá II eda III sem Evrópusambandið telur að ættu að vera tilgreindar í skrá I. Viðaukinn nær enn fremur yfir tegundir, sem njóta ekki verndar samkvæmt ákvæðum samningsins, en falla undir ákvædi i annarri löggjöf Evrópusambandsins. Auk beirra ákvæða sem gilda um tegundir i skrá l eru sérstakar takmarkanir í tengslum við̀ verslun innan landamæra Evrópusambandsins.

Viðauki B: Fyrst og fremst tegundir í skrá II ásamt nokkrum tegundum í skrá III. Í vidaukanum eru einnig tegundir, sem falla ekki undir samninginn, en eru álitnar skapa vistfrædilega ógn fyrir tegundir sem eiga náttúruleg búsvædi í löndum Evrópusambandsins. Heimila má viðskipti með pær samkvæmt ströngum leiðbeiningum.
\end{abstract}

Vidauki C: Tegundir í skrá III. Um pær gilda sömu leiðbeiningar og fyrir tegundir í skrá II en að auki er gerə̀ krafa um innflutningstilkynningu ef pær eru fluttar inn til Evrópusambandsins.

Viðauki D: Tegundir sem eru tilgreindar í skrá III bar sem ríki Evrópusamningsins hafa sett fyrirvara um. Að auki eru par tilgreindar tegundir, sem eru ekki i skrám samningsins, en menn vilja fylgjast med umfangi innflutningsins. Innflutningur til landa Evrópusambandsins er hádur innflutningsleyfi.

\section{www.cites.org}

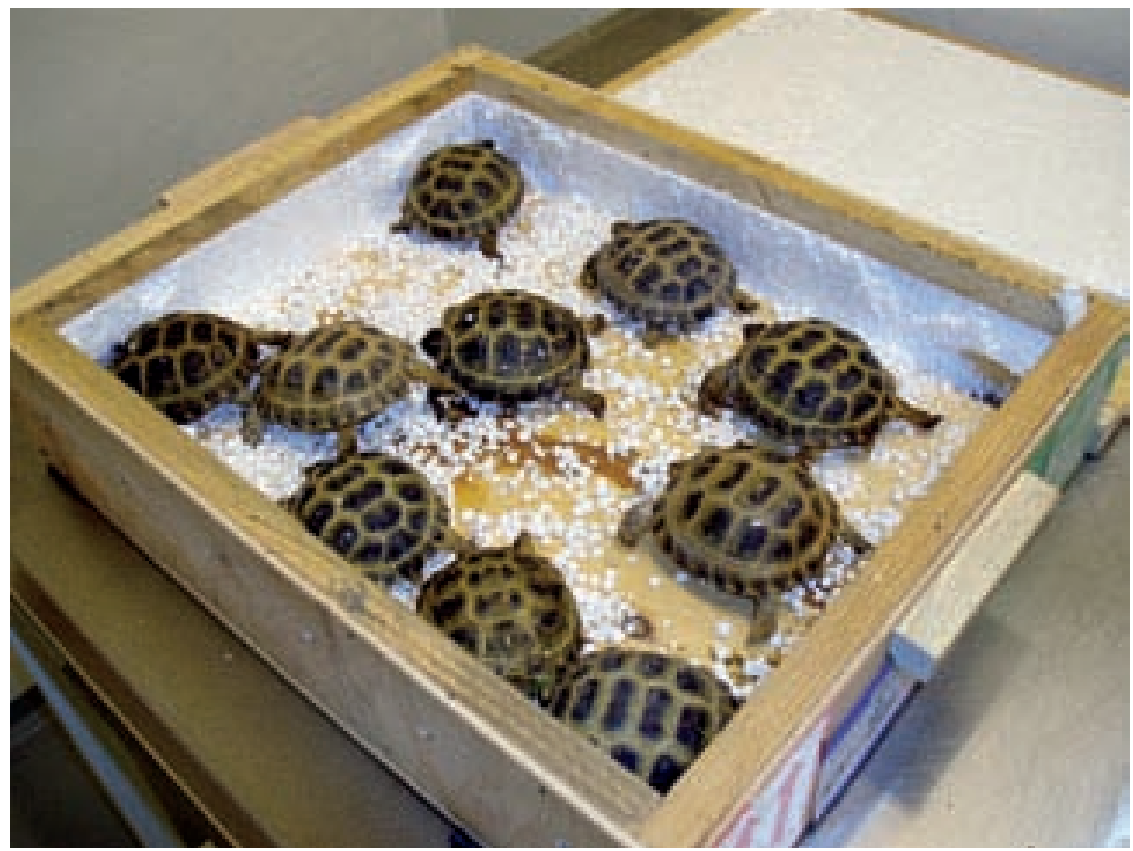

Á hverju ári ganga milljónir lifandi dýra og plantna kaupum og sölum í heiminum öllum til að mæta eftirspurninni eftir gæludýrum og skrautplöntum (ljósm.: Skov-og Naturstyrelsen). 


\title{
Ramsar-samningurinn
}

\author{
Samningurinn um vernd votlendissvæða sem hafa
}

alpjódlegt gildi, einkum sem lífsvæði vatnafugla

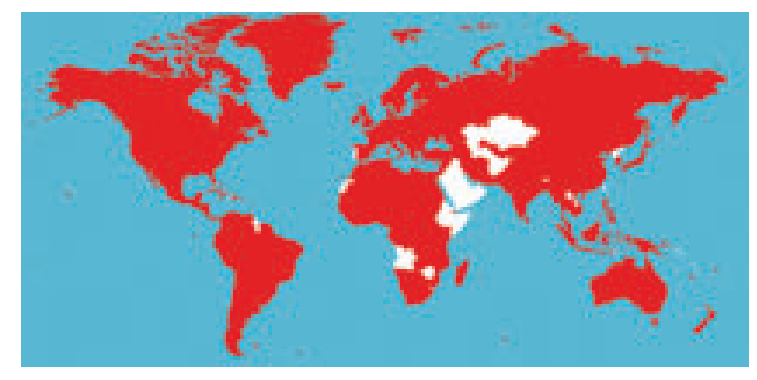

Árið 1971 var „samningurinn um vernd votlendissvæða sem hafa alpjódlegt gildi, einkum sem heimkynni fugla" sampykktur. Í daglegu tali er hann einfaldlega kallaður Ramsar-samningurinn.

Samningurinn öəlaðist gildi árið 1975 og nú hafa 152 lönd fullgilt samninginn, m.a. öll Norðurlöndin. Alls hafa 1629 votlendissvæði verið tilnefnd sem svæði með alpjódlegt gildi fyrir votlendisfugla.

\section{Markmid}

Markmiðið með samningnum er að vernda votlendissvæði sem eru fyrst og fremst búsvæði votlendisfugla. Vernda skal öll svæði sem hafa alpjódlegt gildi fyrir votlendisfugla. Svæði telst hafa alpjóðlegt gildi ef par halda sig að jafnaði 20.000 fuglar af tiltekinni tegund eəa hið minnsta $1 \%$ fugla af tiltekinni tegund eða undirtegund.

Ekki skal aðeins tekið tillit til votlendisfugla á svæðinu, heldur skal vernda allar tegundir dýra og plantna gegn ofnýtingu í pví skyni að varðveita náttúrulega umhverfið.

\section{Ramsar-svæði}

Votlendissvæði eru fjölbreytileg svædi í náttúrunni og tengja saman purrlendi og vatn. I Ramsar-samningnum er votlendissvæði skilgreint á mjög vídtækan hátt. Skilgreiningin tekur m.a. til mýra, flóa, fenja og vatna með fersku, ísöltu eða söltu vatni, par á medal til sjávar par sem dýpi er innan við sex metra.

Svæðin eru ekki aðeins mikilvæg fyrir fugla heldur einnig fyrir margar adrar lífverur. Pau geta til dæmis verið mikilvæg hrygningar- og uppeldissvæði fiska.

\section{Skuldbindingar}

Ríki, sem hafa fullgilt samninginn, skuldbinda sig til að tilnefna hið minnsta eitt votlendissvæði á skrá Ramsar-samningsins og til að vinna að almennri vernd votlendissvæða. Nýting votlendissvæðanna skal vera sjálfbær. Pað merkir að við stjórn svæðanna skal bæði gæta gæða svæðanna og tryggja að nýting peirra til afpreyingar skerði ekki gildi peirra. Aðildarríkin skuldbinda sig jafnframt il pess að stuðla að vernd votlendissvæða og -fugla með bví að setja á stofn friðlönd og ríkin skulu starfa saman ad vernd búsvæða og tegunda á peim votlendissvæðum sem varða pau sameiginlega.

\section{Ramsar-svæə̀i á Norðurlöndum}

Á Norðurlöndum er að finna mjög vídáttumikil votlendissvæði. Paðá einkum vid um Finnland og Svípjód par sem eru mjög víðáttumiklar mýrar og grunn stöðuvötn. Samkvæmt skilgreiningu Ramsar-samningsins eru tæp $25 \%$ af flatarmáli Finnlands og Svípjódar votlendi.

Pann 24. apríl 2006 höfðu Norðurlöndin tilnefnt alls 178 votlendissvæði og er heildarflatarmál peirra $35.682 \mathrm{~km}^{2}$. Fjöldi og stærd svædanna sýna að votlendissvæði Norðurlandanna hafa mikið gildi fyrir margar tegundir votlendisfugla. 


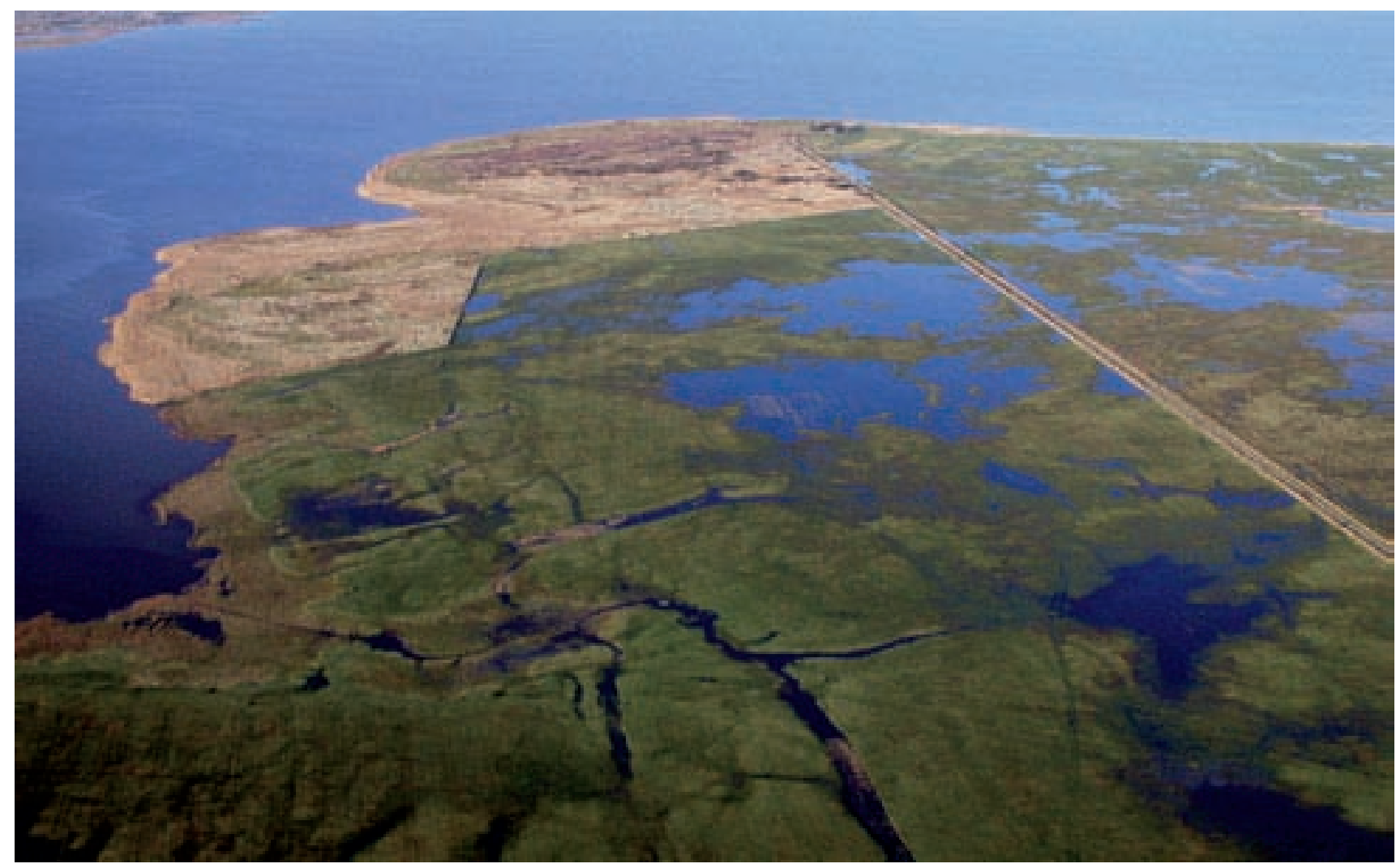

Ríkin sem hafa gerst aðilar að Ramsar-samningnum eru skuldbundin til að tilgreina að minnsta kosti eitt Ramsar-svæði og til að efla vernd votlendis með pví að friðlýsa svæði. Tipperne í Ringkøbing-firði er eitt peirra friðlýstu svæða sem sett hafa verið á fót í Danmörku (ljósm.: Jens Muff Hansen/Naturplan).

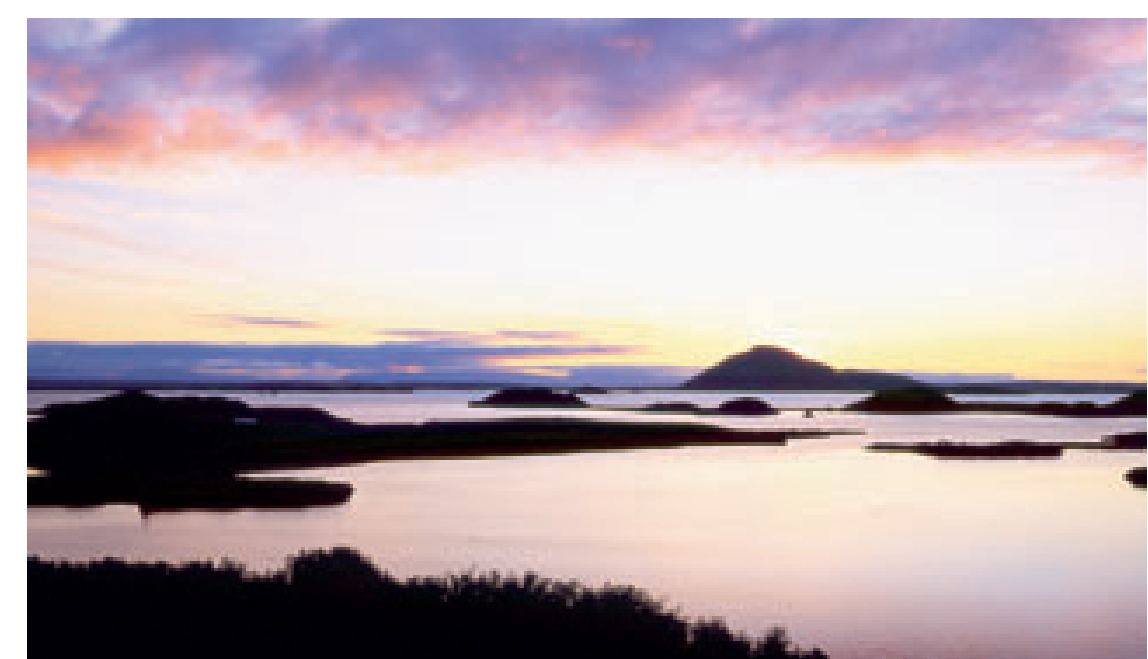

Mývatn státar af einstaklega fjölskrúðugu fuglalífi og hefur verið tilnefnt sem svæði með alpjódlegt gildi (ljósm.: Árni Einarsson). 


\section{Bernarsamningurinn}

\section{Samningurinn um vernd villtra dýra og plantna og búsvæda peirra í Evrópu}

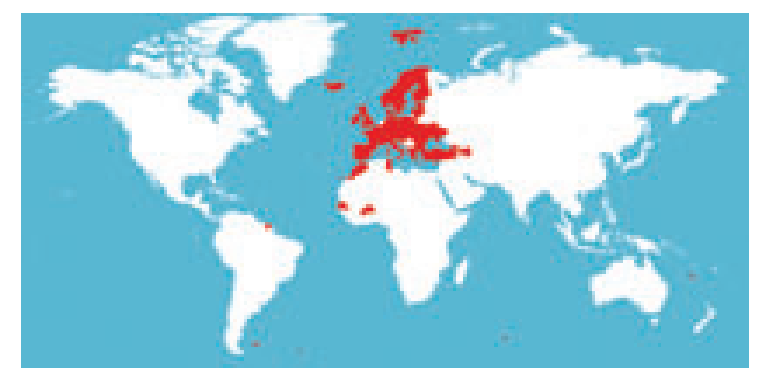

Bernarsamningurinn, sem var sampykktur árið 1979, fjallar um vernd evrópskra tegunda villtra dýra, plantna og búsvæði peirra. Aðilar að samningnum eru ESB og 45 ríki i Evrópu og Afríku. Aəa auki hafa nokkur ríki áheyrnarrétt.

Öll Norðurlöndin, að undanskildu Grænlandi og Færeyjum, hafa fullgilt samninginn.

\section{Markmid}

Markmiðið með Bernarsamningnum er að vernda dýr og plöntur og heimkynni peirra. Margar tegundir og búsvædi peirra eru í hættu eəa eru viðkvæm og til að tryggja að pau hverfi ekki er naudsynlegt aə taka sérstakt tillit til peirra. Einnig er gerð krafa um að vernda sérstaklega tegundir fardýra.

Samningnum er ætlað - auk pess að vernda tegundir og búsvæði peirra - að stuðla ad samstarfi og samræmingu medal einstakra ríkja, bví að auðveldara er að ná markmiðum samningsins ef samstarf er haft um pessi mál.

\section{Eðli samningsins}

Pær tegundir plantna og dýra, sem samningurinn tekur til, eru tilgreindar í premur skrám (1. rammi). Munurinn á skránum er fólginn í peirri hættu sem steðjar að tegundunum og hve viðkvæmar pær eru. Fjórda skráin fjallar um bannadar veiðiaðferðir og veiðibúnað.

Skrá I tekur fyrst og fremst til suðurevrópskra plöntutegunda, en par eru líka tilgreindar allmargar norrænar tegundir, m.a. bogabroddi og gullbrá.

Skrá ll tekur einnig til margra norrænna tegunda, t.d. blápyrils, hnísu, úlfs, skógarbjarnar, ránfugla og uglna.

Skrá III tekur til nær allra evrópskra spendýra, p.m.t. er bjór, fugla, p.m.t. er rjúpa, skriðdýra og froskdýra, svo og til nokkurra fisktegunda sem eru ekki í skrá II.

\section{Stjórnun}

Framkvæmd samningsins er undir stjórn nefndar sem í eru fulltrúar adildarríkjanna og ríkja sem hafa áheyrnarstöðu. Nefndinni er ætlað að tryggja að ríkin fari að ákvæðum samningsins. Henni er líka ætlað að koma með tillögur um hvernig innleida megi ákvæði samningsins í löggjöf ríkjanna.

Nokkrar óopinberar stofnanir eiga enn fremur fulltrúa í nefndinni. Peir gegna par mikilvægu hlutverki pví að peir eru oft fyrstir til að bregðast við í málum sem varða vernd eða vöktun.

Bernarsamningurinn á pátt í pví aə flestar tegundir froskdýra og skriðdýra á Norðurlöndunum hafa verið friðaðar. 


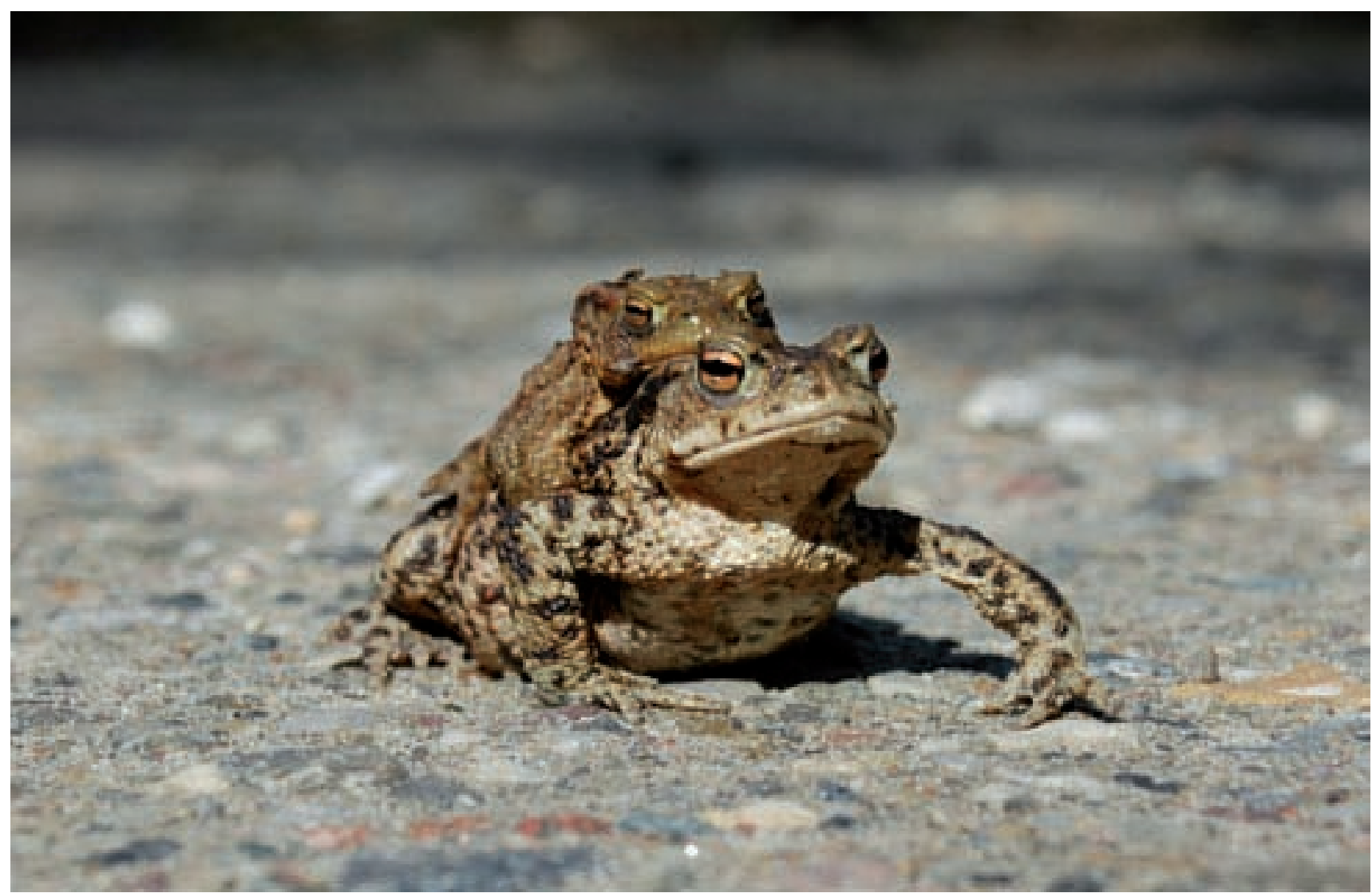

Hnúðkartan (Bufo bufo) er ein af peim tegundum í skrá III í samningnum par sem veiðum er stjórnað. pau froskdýr, sem eru ekki nú pegar i skrá II, eru tilgreind i skrá III (ljósm.: Birthe Overgaard/Naturplan).

\section{1. rammi}

Skrá I: Tegundir plantna sem njóta strangrar verndar. Tegundirnar eru svo hætt komnar ad aðildarríkin hafa skuldbundið sig til að tryggja à pessar tegundir og vaxtarstadir peirra njóti sérstakrar verndar.

Skrá II: Tegundir dýra sem njóta strangrar verndar. Aðildarríkin skulu vernda dýrin og heimkynni peirra, t.d. í tengslum við veiðar, söfnun, tínslu o.p.h., truflun og viðskipti med tegundirnar, ef pessir pættir hafa áhrif á vernd peirra.

Skrá III: Tegundir sem eru veiddar og par sem veiðunum skal stjórnad. Nær allar evrópskar tegundir, sem eru ekki í skrá II, eru í skrá III. Gert er rád fyrir pví ad̀ nýting tegundanna sé stjórnad pannig ad tryggt sé ad stofnarnir séu ekki settir í hættu.

Skrá IV: Bannaður veiðibúnaður og veiðiaðferdir. Bannad er m.a. að nota hálf- eda alsjálfvirk vopn við veiðar, að̀ nota snörur til ad veida spendýr og nota eitrad agn.

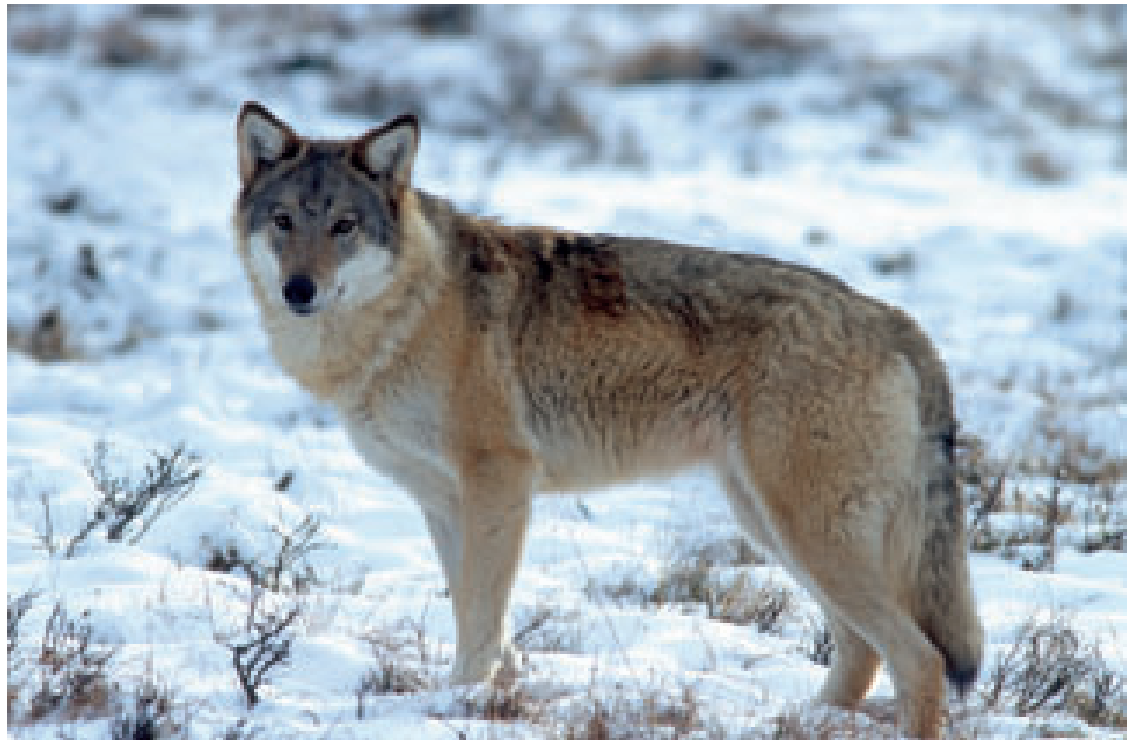

Nokkrar tegundir eru í svo mikilli útrýmingarhættu að aðildarríkjunum er skylt að gera sérstakt átak til pess að vernda pær og búsvæði peirra. Úlfurinn (Canis lupus) er ein bessara tegunda (ljósm.: Baard Næss/NN/Polfoto). www.conventions.coe.int CETS No.: 104 


\section{Bonn-samningurinn}

\section{Samningur um villtar fartegundir dýra}

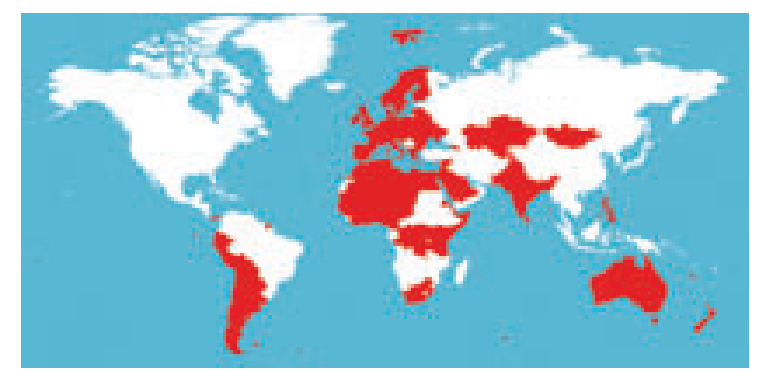

Mörg dýr fara reglulega yfir landamæri ríkja á ferðum sínum milli

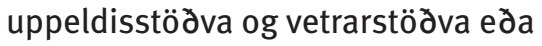
pegar pau ferdast í ætisleit. Petta á við um farfugla, hvali, fiska og ýmis önnur dýr.

\section{Markmið}

Markmið samningsins er að vernda villtar dýrategundir sem fara reglubundið yfir landamæri. Aə̇ildarlöndin eru skuldbundin til pess à vernda dýrategundir sem eru í hættu og gera samninga um samstarf sem tryggir betri vernd dýranna á ferðum peirra. Markmiðið er að dýrin njóti ákjósanlegrar verndar.

\section{Skrár}

Teknar hafa verið saman tvær skrár yfir dýrategundir í hættu (1. rammi).

\section{Sérstakt átak varðandi tegundir í skrá I}

Aðildarlöndunum er skylt að beita sér fyrir sérstöku átaki varðandi tegundir í skrá I. Löndin skulu vernda búsvæði tegundanna og endurreisa eəa endurskapa heimkynni peirra. Reyndin verður oft sú að verndin leiðir til pess að tegundin og/eða heimkynni hennar verða friðlýst.

Aðildarlöndin skulu auk pess freista pess að beita sér gagnvart peim aðstæðum eða peirri starfsemi sem orsakar pad að tegundinni er ógnað. Petta á til dæmis við um veiðar.

\section{Samstarf varðandi tegundir í skrá II}

Fyrir tegundir í skrá Il koma tvenns konar samstarfssamningar til greina. Fyrri gerðin hefur að markmiði að taka til allra landa á útbreiðslusvæði dýrategundar. Samningurinn tekur einnig til landa sem hafa ekki fullgilt Bonn-samninginn.

Hin gerð samstarfssamninga gildir pegar um er að ræða dýr sem fara aðeins ödru hverju yfir landamæri. Pessir samningar taka ekki i öllum tilvikum til allra landa á útbreiðslusvæði viðkomandi tegundar.
Dæmi um tegundir sem eru tilgreindar í skránum

I skrá I eru yfir 100 tegundir, en i skrá ll eru tilgreindar yfir 1000 tegundir. Í skrá I eru til að mynda engirella, haförn, hnúfubakur og norðhvalur.

Í skrá II eru m.a. búrhvalur, landselur og lómur.

92 lönd hafa fullgilt samninginn, m.a. Norðurlöndin, að Íslandi undanskildu.
1. rammi:

Skrá I: Tegundir sem eru í útrýmingarhættu á öllu útbreiðslusvæði sínu eða hlutum pess.

Skrá II: Tegundir sem nauðsynlegt er að milliríkjasamkomulag gildi um eða sem njóta góds af slíku samkomulagi.

www.cms.int 


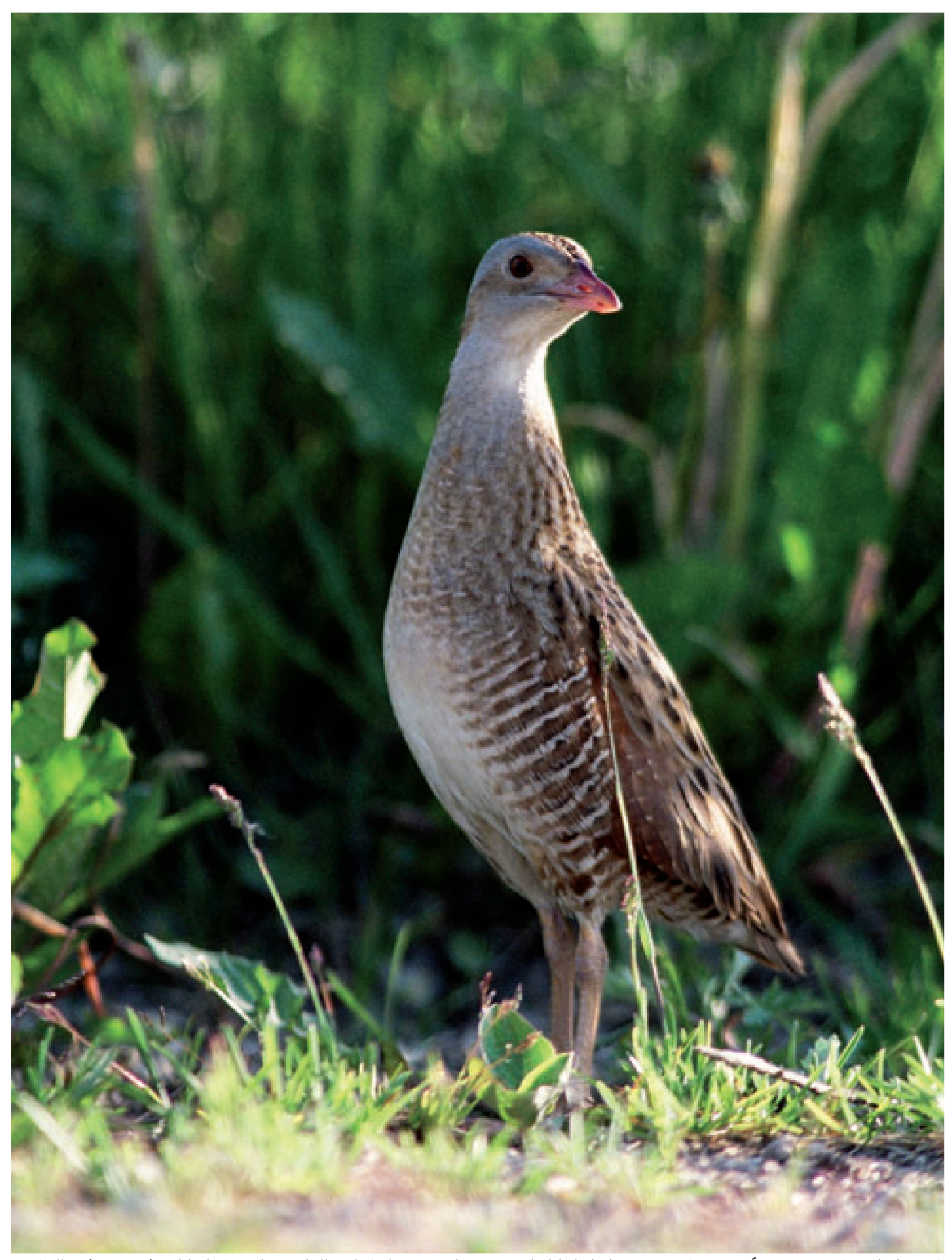

Engirellan (Crex crex) er í útrýmingarhættu í öllum heimkynnum sínum og er pví á skrá I i Bonnsamningnum. Á mörgum stöðum hefur verið gripið til aðgerða í pví skyni að búa til eða endurheimta búsvæði fyrir tegundina (ljósm.: Aivars Petrins/Naturplan). 


\section{Alpjódlegir samstarfssamningar} AEWA, EUROBATS og ASCOBANS eru einna vídtækustu samstarfssamningarnir sem gerðir hafa verid samkvæmt Bonn-samningnum.

\section{AEWA (African-Eurasian Waterbird Agreement)}

Markmiðið með AEWA er að vernda vatnafugla sem fara milli Afríku, Evrópu og Asíu. Margir vatnafuglanna fljúga langar leiðir og fara pá yfir landamæri margra ríkja. Af peim sökum er pörf á alpjódlegum samstarfssamningum til að tryggja að fuglarnir njóti peirrar verndar sem best verður á kosið á varp- og dvalarstödum peirra og í peim löndum sem peir fara um í farflugi sínu. Löndin sem hafa gerst adilar aə samningnum skuldbinda sig t.d. til pess að vernda og endurskapa heimkynni tegundanna og setja af stað rannsóknaráætlanir í bví skyni að skapa fuglunum betri skilyrði.

Samningurinn tekur til 235 tegunda vatnafugla sem dvelja allt árið eða hluta pess á votlendissvæðum.

Alls hafa 53 lönd - m.a. Danmörk, Finnland og Svípjód - gerst adilar ad samningnum sem tekur til allrar Afríku og Evrópu, hluta Asíu og nokkurra svæda á norðurheimskautssvædinu.

\section{EUROBATS (The Agreement on the Conservation of Populations of European Bats)}

Markmið samningsins er à vernda ledurblökur í Evrópu. Med adild ad samningnum skuldbinda löndin sig til að̀ veita upplýsingar um leðurblökur og setja löggjöf um pær og til að starfa með peim löndum sem hafa ekki fullgilt Bonn-samninginn. Margar tegundir leðurblakna eru nú í hættu vegna pess ad mörg af heppilegum búsvæðum peirra hafa glatast. Verri lífsskilyrdi stafa m.a. af notkun varnarefna og pörf er á aukinni vitneskju um líffrædi og heimkynni leðurblaknanna. Samningurinn tekur til allra 45 tegunda leðurblakna í Evrópu.

Alls hafa 48 lönd gerst aðilar ad samningnum, m.a. Danmörk, Finnland, Noregur og Svípjód.

\section{ASCOBANS (Agreement on the Conservation of Small Cetaceans of the Baltic and North Seas)}

Markmið ASCOBANS-samningsins er að vernda tegundir smárra tannhvala í Eystrasalti og Norðursjó. Allir tannhvalir, að búrhval undanskildum, falla undir samninginn. Löndin, sem hafa gerst aðilar ad samningnum, skuldbinda sig til að stuðla aə̀ vernd hvalategunda sinna með pví að hrinda af stað ýmiss konar rannsóknar- og stjórnunarverkefnum.

Nú hafa Belgía, Danmörk, Finnland, Frakkland, Pýskaland, Litháen,
Holland, Pólland, Svípjód og StóraBretland gengist undir ákvæði samningsins.

Ápekkur samningur, ACCOBAMS, er í gildi fyrir tegundir smárra tannhvala í Miðjarðarhafinu og á aðliggjandi siglingaleiðum.

Frekari upplýsingar um samstarfssamningana prjá:

www.unep-aewa.org www.eurobats.org www.ascobans.org 


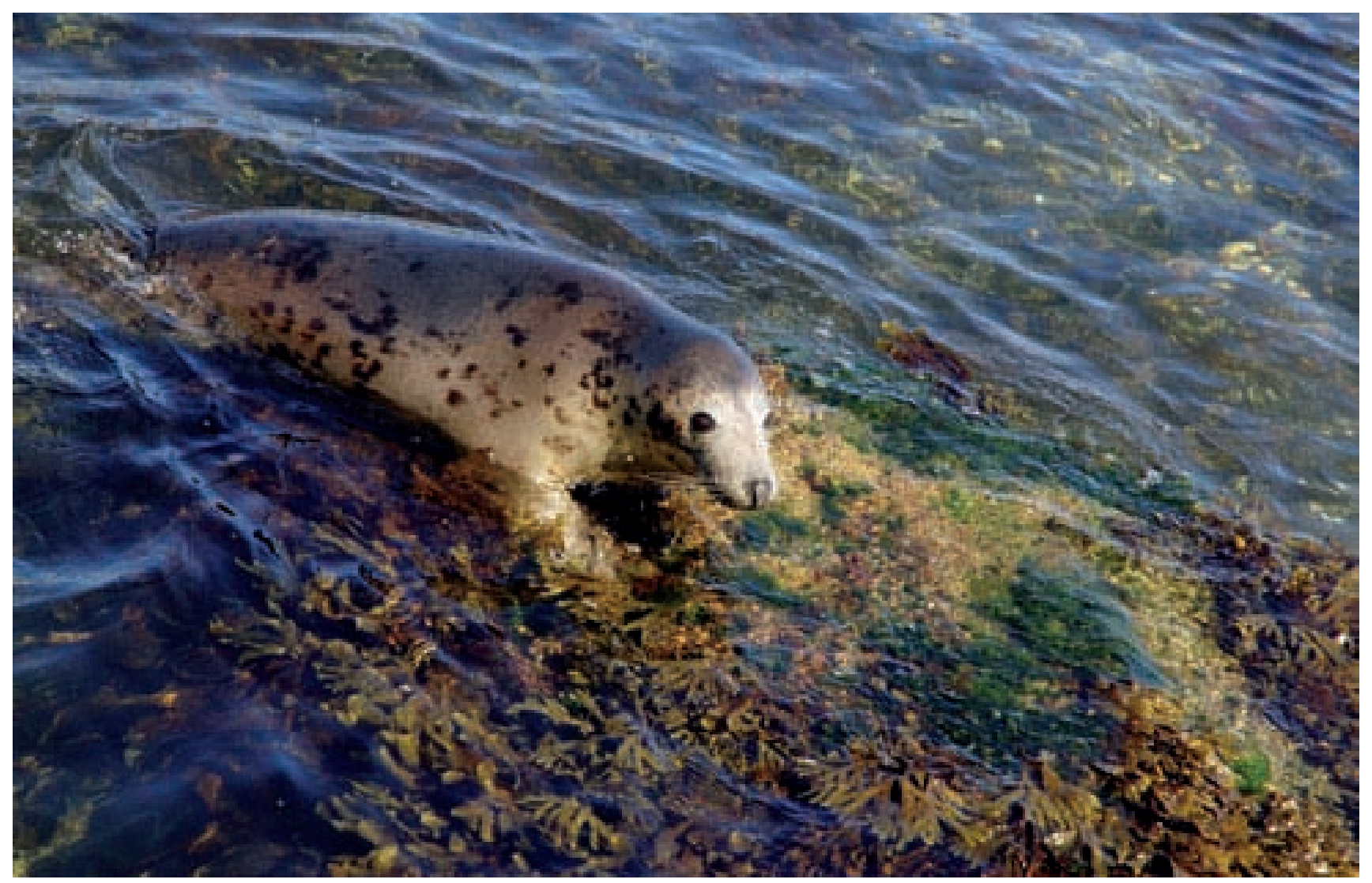

Landselur (Phoca vitulina) er í skrá ll í samningnum. Pýskaland, Holland og Danmörk hafa gert með sér samning um vernd landsela í Vadehavet. Markmiðið með samningnum er að skapa selunum svo góð lífsskilyrði að stofninn komist vel af (ljósm.: Stig Bachmann Nielsen/Naturplan).

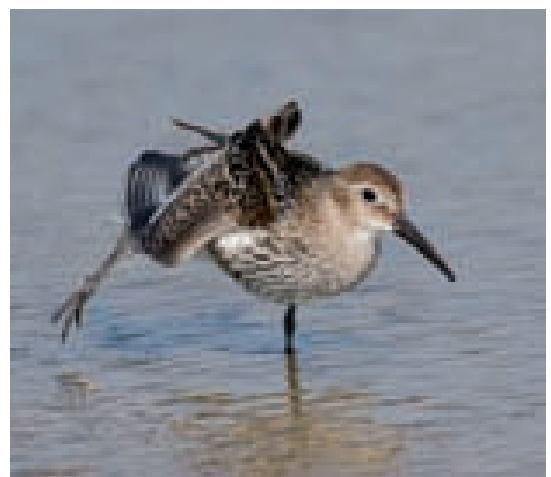

Lóupræll (Calidris alpina) er í hópi peirra 235 fuglategunda sem falla undir samstarfssamninginn um vatnafugla sem fara milli Afríku, Asíu og Evrópu (ljósm: Klaus Mortensen/Naturplan).

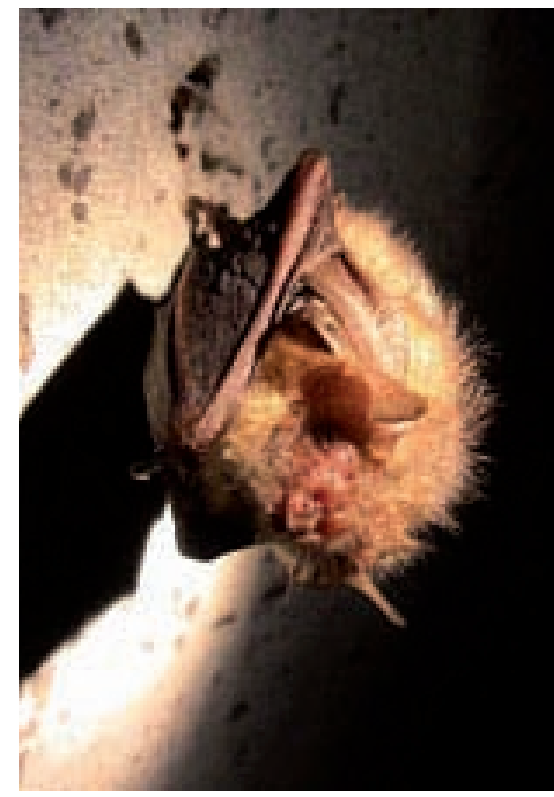

EUROBATS er samstarfssamningur 48 landa. Markmiðið með samningnum er að bæta lifsskilyrdi almennt fyrir ledurblökur (ljósm.: Andis Liepa/Naturplan). 


\section{Hvalveiðisamningurinn}

Samningurinn um stjórnun hvalveiða

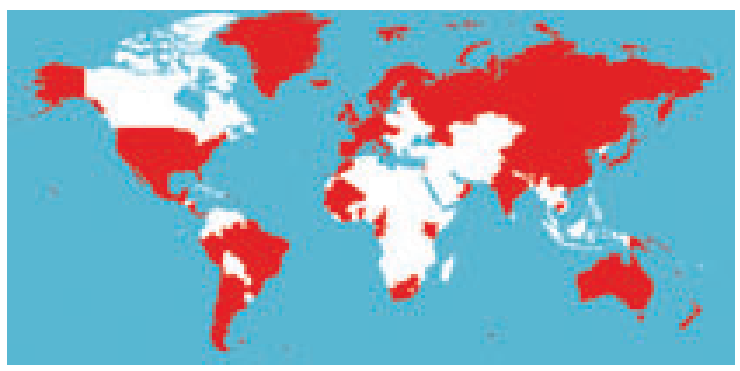

Á fjórda áratug 20. aldar stunduðu margar pjódir miklar hvalveiðar. petta leiddi til pess ad mikil hætta var á að hvölum yrði útrýmt. Noregur og England gerðu með sér samning pegar árið 1931 um að takmarka hvalveiðar til að vernda stofnana. Árið 1937 gerðust fleiri lönd aðilar að̀ samningnum, en hann reyndist ekki mjög árangursríkur pví að stöðugt bættust ný lönd við í hóp hvalveiðipjóda. Nauðsynlegt var að koma á nýrri stjórnun og á grundvelli pess sampykktu 15 hvalveiðipjódir hvalveiðisamninginn árið 1946. Á árunum fyrir og eftir 1980 fullgiltu mörg ný lönd hvalveiðisamninginn. Flest pessara nýju aðildarlanda unnu í meginatriðum að pví að stöəva hvalveiðar með öllu eða takmarka pær verulega.

\section{Markmið}

Markmiðið með samningnum er að stjórna stofnum stórhvela heimsins og vernda pá. Petta skal medal annars gert með pví að stjórna veiðum á tegundum stórhvela.

\section{Framkvæmd samningsins}

Framkvæmd hvalveiðisamningsins er í höndum Albjódahvalveiðirádsins sem ákveður hvalveiðikvóta á grundvelli vísindalegra gagna. Kvótarnir eru ákveðnir út frá mati á stofnstærð hvala og fjölgun peirra og á grundvelli heilbrigðisástands peirra, umhverfismengunar, meðafla í tengslum við fiskveiðar, loftslagsbreytinga, truflana og skipaumferðar.

\section{Hvalveiðibann}

Árið 1986 sampykkti hvalveiðirádið bann við veiðum á tegundum stórhvela í atvinnuskyni, en veiðar í vísindaskyni voru pó undanskildar. ÆEtlunin var að bannið gilti i fimm ár meðan hvalveiðirádið ynni að umfangsmiklu mati á hvalastofnum. Bannið hefur sídan verið framlengt og er enn í gildi. Norðmenn settu fyrirvara við bannið og veiða enn hrefnur.

\section{Hvalveiðipjódir frá fornu fari} Litið er á hvalveiðar á Grænlandi sem hefəbundnar veiðar frumbyggja og Grænlendingar hafa leyfi til ad veiða tiltekinn fjölda stórhvela á ári hverju.

\section{Friðlýsing tegundar eəa svæða}

Hvalveiðisamningurinn gefur kost á að haga friðlýsingu á tvo vegu. Annað hvort geta menn friðlýst tegundir hvala eða tilgreint hafsvæði par sem bannað er að veida hvali.

Árid 1979 var t.d. sett bann við hvalveiðum á Indlandshafi og árid 1994 voru hvalir friðlýstir í hafinu umhverfis Suðurskautslandið.

\section{Smáhveli}

Samningurinn tekur ekki til smáhvela. Smáhveli njóta verndar samkvæmt CITES-samningnum, Bernarsamningnum og Bonn-samningnum.

\section{Adildarlönd}

Nú eiga 70 lönd aðild að hvalveiðisamningnum, en fæst peirra stunda pó hvalveiðar af nokkru tagi. Öll Norðurlöndin eru aðilar að hvalveiðisamningnum. 


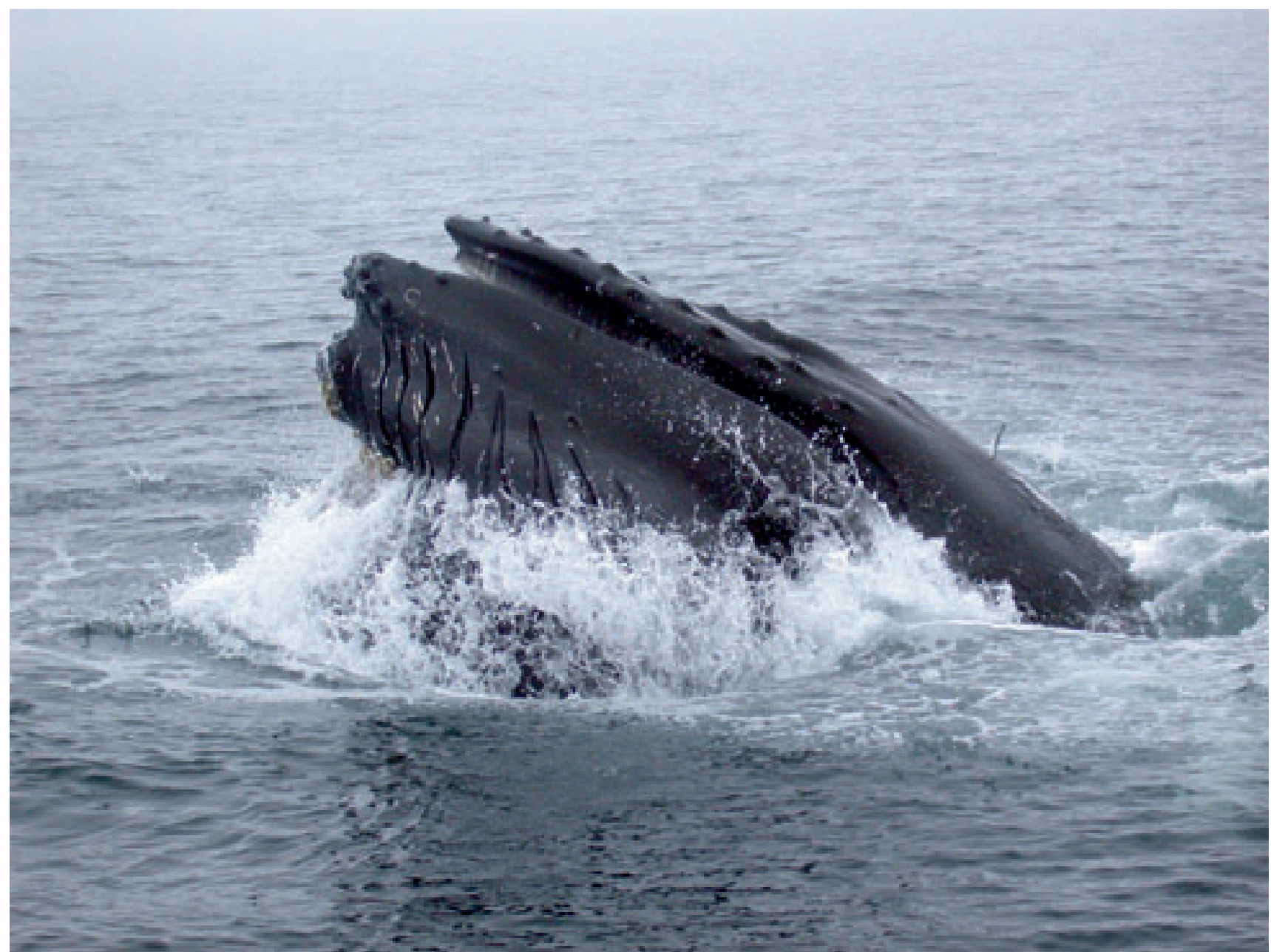

Í kjölfar hvalveiða um áratugi var svo gengið á stofna stórhvela að hvalveiðiráðið kvað á um bann við veiðum íatvinnuskyni. Hvalveiðibannið tekur m.a. til hnúfubaksins (Megaptera novaeangliae) (ljósm.: Jens Muff Hansen/Naturplan).

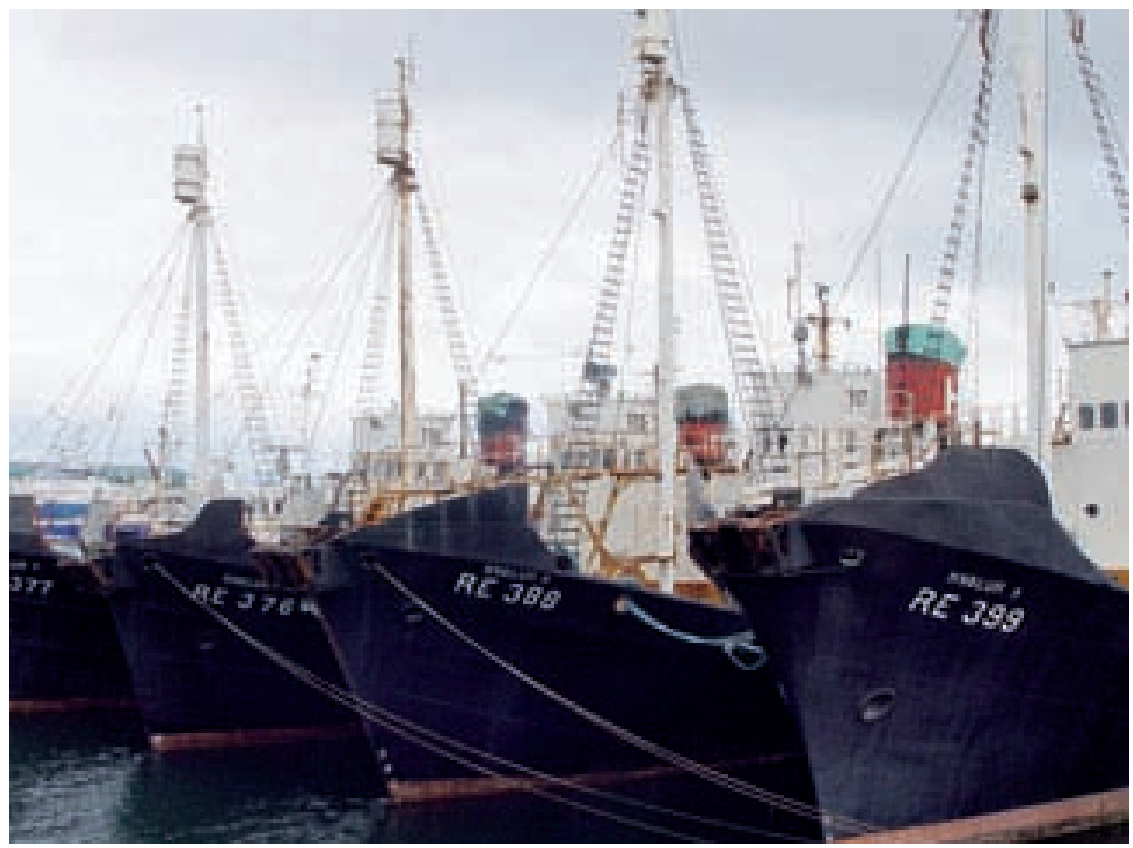

Hvalveiðiskip við bryggju í Reykjavík (ljósm.: Torben Christensen/Scanpix). 


\section{Helsingfors-samningurinn}

\section{Samningurinn um vernd hafsvæðisins á Eystrasaltssvæðinu}

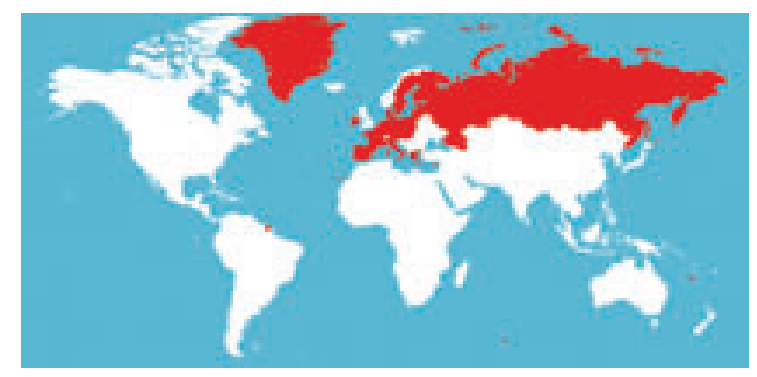

Adstreymi næringarefna og mengandi efna, ásamt ofveiði og vaxandi skipaumferð, hefur sífellt meiri umhverfisvanda í för með sér í Eystrasalti. Margar tegundir lífvera á svæðinu eru annaðhvort horfnar eəa pær eru í hættu vegna mengunar og ofveidi.

Vegna bágs ástands Eystrasaltsins sampykktu pau sjö lönd, sem pá lágu ad Eystrasaltinu, Helsingfors-samninginn árið 1974. Samningurinn var fyrsti albjódlegi samningurinn sem fjalladi um allar tegundir mengandi uppsprettna, p.m.t. adstreymi næringarefna og mengandi efna frá upplandi við Eystrasaltið og losun úrgangs frá skipum og flugvélum í hafid.

Árið 1992 sampykktu alls níu ríki við Eystrasaltið og Evrópubandalagid nýjan samning sem kom í stad samningsins frá 1974. Í samningnum var bætt við ákvæðum um vernd líffræðilegrar fjölbreytni og frá árinu 1999 hefur hann einnig tekið til stjórnunar á strandsvæðum og vatnsfalla sem renna yfir landamæri.

\section{Markmið}

Markmiðið með samningnum er að stödva alla mengun á svæðinu og að skapa betri skilyrði í öllu Eystrasaltinu í heild. Nú tekur samningurinn til hafsins, hafsbotnsins og alls upplands við Eystrasaltið, svæðis sem er að heildarflatarmáli um $415.000 \mathrm{~km}^{2}$.

\section{Helsingfors-nefndin}

Helsingfors-nefndin, sem skipud er fulltrúum adildarlandanna, á að sjá til pess að samningnum verði hrint í framkvæmd. Nefndin ber ábyrgð á að vakta ástand umhverfisins og skal með ákvörðunum sínum og tilmælum stuðla að bví að mengun minnki og aə líffræðileg fjölbreytni verði varðveitt. Frá upphafi áttunda áratugar sídustu aldar hefur Helsingfors-nefndin sett fram yfir 200 tilmæli.

Hvert ríki ber sjálft ábyrgð á pví að tilmælin verði felld inn í löggjöf pess. Nefndin getur bví aðeins tekið ákvörðun eða gert með sér samkomulag að allir nefndarmenn séu sammála um pad.

\section{Skuldbindingar}

Aðildarríkin skuldbinda sig til að koma í veg fyrir hvers kyns mengun sem skaðað getur vistkerfi Eystrasalts. Ef aðildarríki mengar hafið skal pað sjálft greiða fyrir hreinsunina. Pessi meginregla, ad sá er veldur mengun skuli greiða fyrir hreinsun, er sett til að tryggja að enginn hafi efnahagslegan ávinning af pví að veita úrgangsefnum i vistkerfi hafsins. Pvert á móti verður bað til hagsbóta fyrir hvert ríki að komast hjá pví ad menga pví aə mengunin hefur í för med sér efnahagslegar afleiðingar vegna hreinsunar.

Auk peirrar skyldu aðildarríkjanna aəd draga úr mengun Eystrasalts er peim einnig skylt að vakta ástand umhverfisins á svæðinu.

Pótt ofveiði eigi pátt í að margar tegundir lífvera séu i hættu á Eystrasaltssvæðinu falla fiskveiðar ekki undir samninginn. Ákvæði samningsins ná pó til áhrifa fiskveiða á sjávarvistkerfin. 


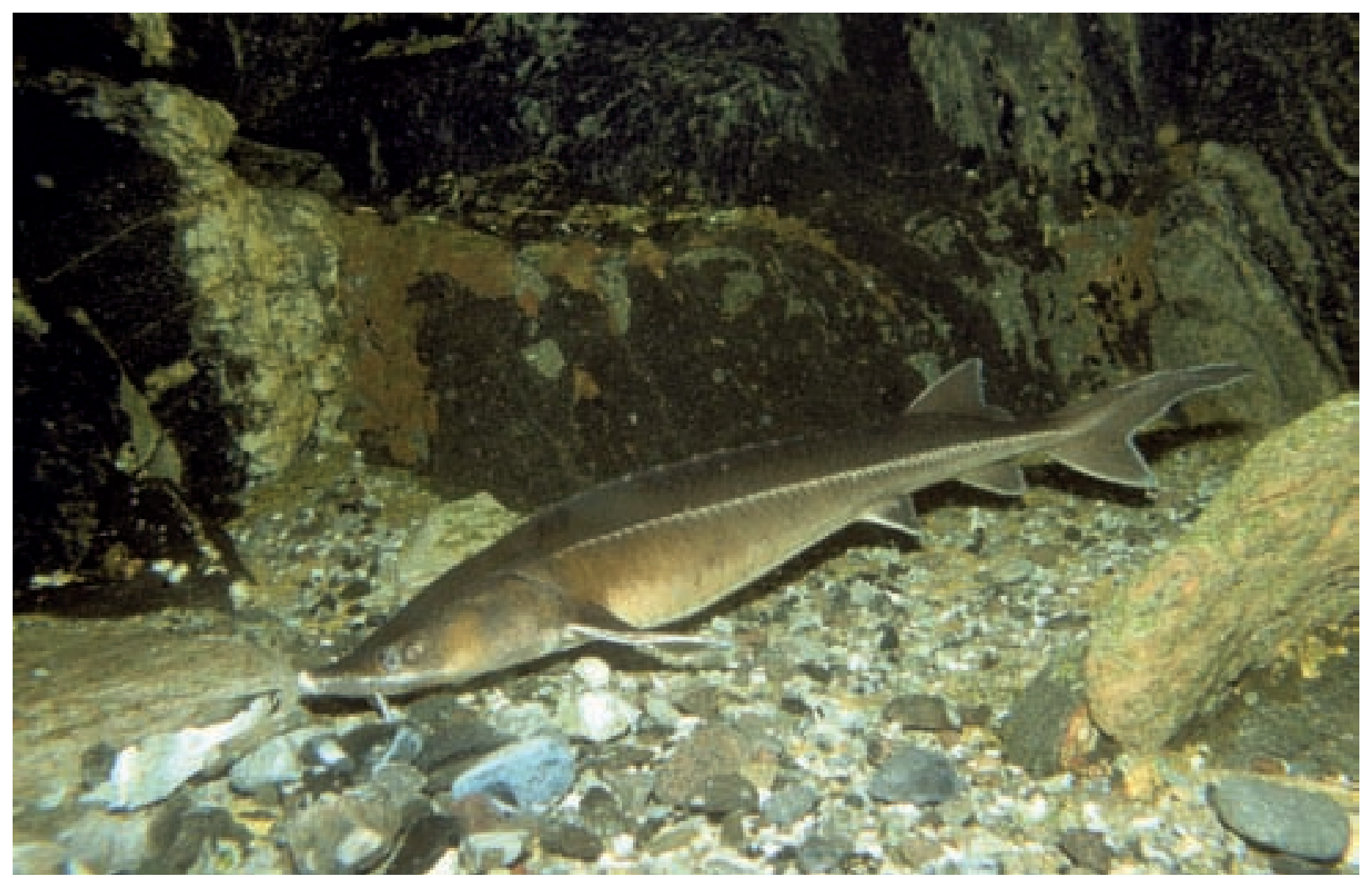

Margar tegundir lífvera í Eystrasaltinu eru í hættu vegna mengunar og ofveiða. Styrja (Acipenser sturio) var fyrrum algengur fiskur á pessu svæði, en er nú horfin með öllu (ljósm.: Lars Laursen/Scanpix).

Níu ríki - auk ESB - hafa fullgilt samninginn. Pau eru Svípjód, Finnland, Danmörk, Eistland, Lettland, Litháen, Pólland, Rússland og Pýskaland.

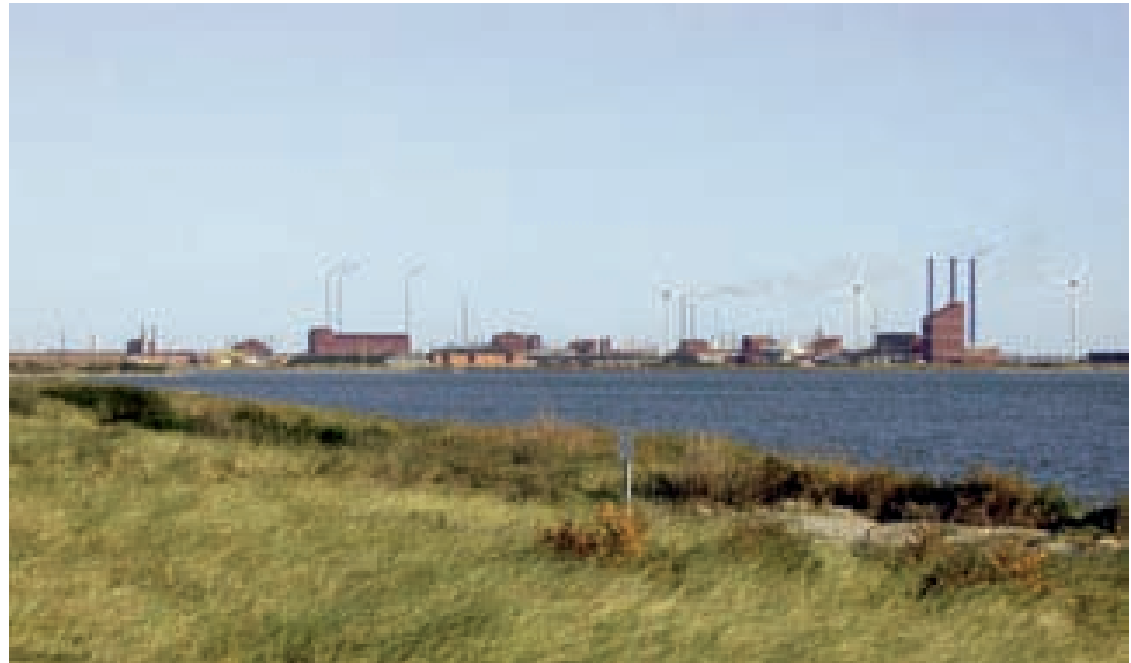

Ein helsta orsök pess að ástand Eystrasaltsins er svo bágt sem raun ber vitni er að næringarefni og mengandi efni berast í pad i of miklum mæli. Helsingfors-samningnum er ætlaða að tryggja að enginn hafi hag af pví að sleppa mengandi efnum í hafið (ljósm.: Stig Bachmann Nielsen/Naturplan). 


\section{OSPAR-samningurinn}

\section{Samningurinn um vernd Norðaustur-Atlantshafsins}

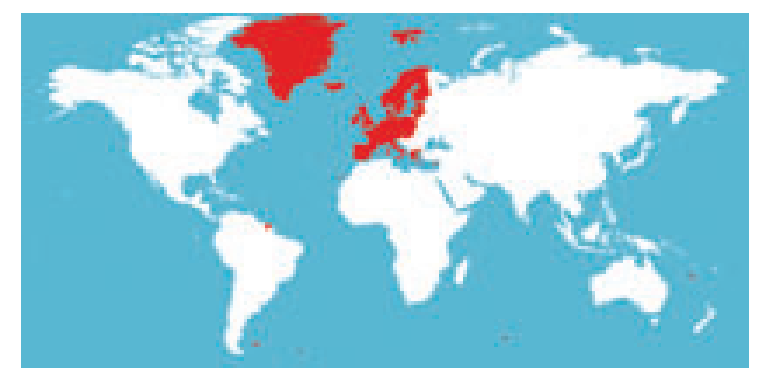

OSPAR-samningurinn fjallar um vernd Norðaustur-Atlantshafsins, p.m.t. Kattegat og Norðursjóinn. Samningurinn varð til við samruna Parísar- og Oslóarsamningsins sem fjölluðu um mengun frá landi og losun úrgangs frá skipum og flugvélum. Af hálfu ríkjanna við Norðaustur-Atlantshafið var ekki talið að eldri samningarnir tveir tryggðu nægilega vernd hafsins gegn öllum upptökum mengunar. Árið 1992 var pví ákvedið ad sampykkja nýja samninginn sem tekur til allra umsvifa mannsins sem stuðlar að mengun NorðausturAtlantshafsins.

\section{Markmið}

Árum saman hefur maðurinn mengað Norðaustur-Atlantshafið með margs konar úrgangsefnum. Pessi mengun hefur haft óheppilegar afleiðingar fyrir plöntu- og dýralíf hafsins. AEtlunin með OSPARsamningnum var að varðveita líffræðilega fjölbreytni hafsvæðisins og stuðla að endurheimt fyrri fjölbreytni með pví að koma með öllu í veg fyrir að úrgangsefnum væri veitt eða sleppt í hafið.

\section{OSPAR-nefndin}

OSPAR-samningurinn er undir stjórn OSPAR-nefndarinnar sem skipud er fulltrúum allra aðildarríkjanna. Nefndin leggur tilmæli og rádleggingar fyrir adildarríkin og hefur meðal annars lagt bann við að olíu sé sleppt í hafì frá olíuborpöllum og takmarkað heimildir til að sleppa geislavirkum efnum í sjó. Nefndin leggur enn fremur ríka áherslu á ad efla umhverfisvöktun og vöktun mengandi uppsprettna.

Nefndin hefur ekki vald til pess að taka ákvarðanir um stjórn fiskveiða.

\section{Vistgerðir og tegundir lífvera í} mikilli hættu

OSPAR-nefndin hefur til brádabirgda tilnefnt 14 mismunandi vistgerðir og búsvæði og nokkurn fjölda dýrategunda, sem eru i útrýmingarhættu, og aðildarlöndunum er falin sérstök ábyrgð meə peim. Par er um að ræða bæði spendýr, fiska, lindýr, skriðdýr og fugla.

Meðal peirra vistgerða, sem njóta sérstakrar verndar og finnast á Norðurlöndunum, eru sjávarleirur, svæði með marhálmi og ostrumið.
Tegundir, sem lifa í Norðursjó og parfnast sérstakrar verndar, eru m.a. nákuðungur, styrja, steypireyður og rodaperna.

OSPAR-nefndin hefur m.a. sett sér pad markmið að koma á fót neti verndaðra svæða i NorðausturAtlantshafinu. Nefndin hefur sett sér viðmiðanir til að fara eftir við val og stjórn á peim svæðum sem njóta skulu sérstakrar verndar.

\section{Adildarríki}

15 ríki - auk ESB - hafa fullgilt samninginn, p. á m. öll Norðurlöndin. 


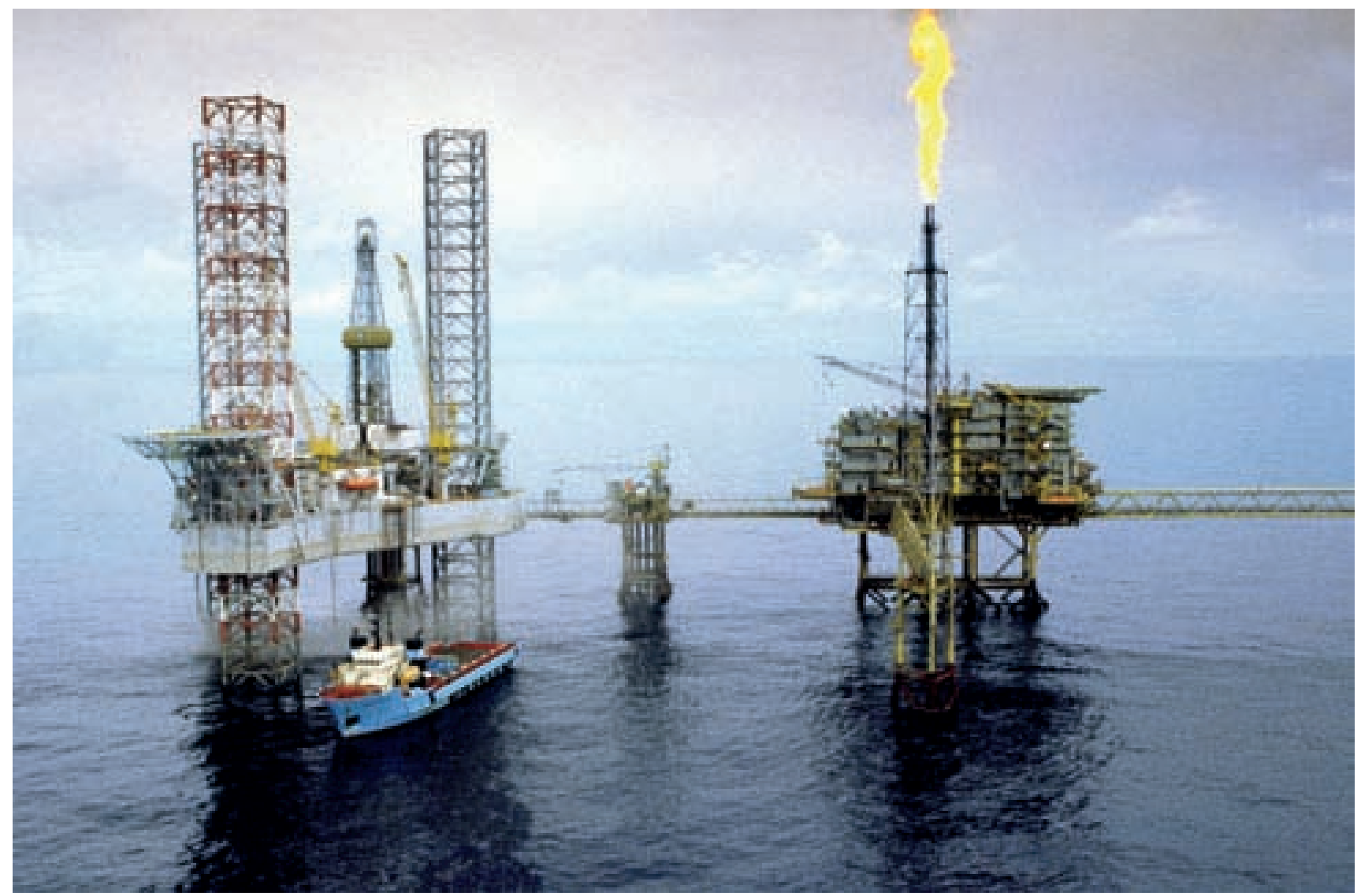

Á̉ur var leyfilegt að kasta úrgangi i sjó frá olíuborpöllum en OSPAR-nefndin hefur nú sett algert bann vỉ sleppingu mengandi efna í hafid (ljósm.: Steen Jacobsen/Scanpix).

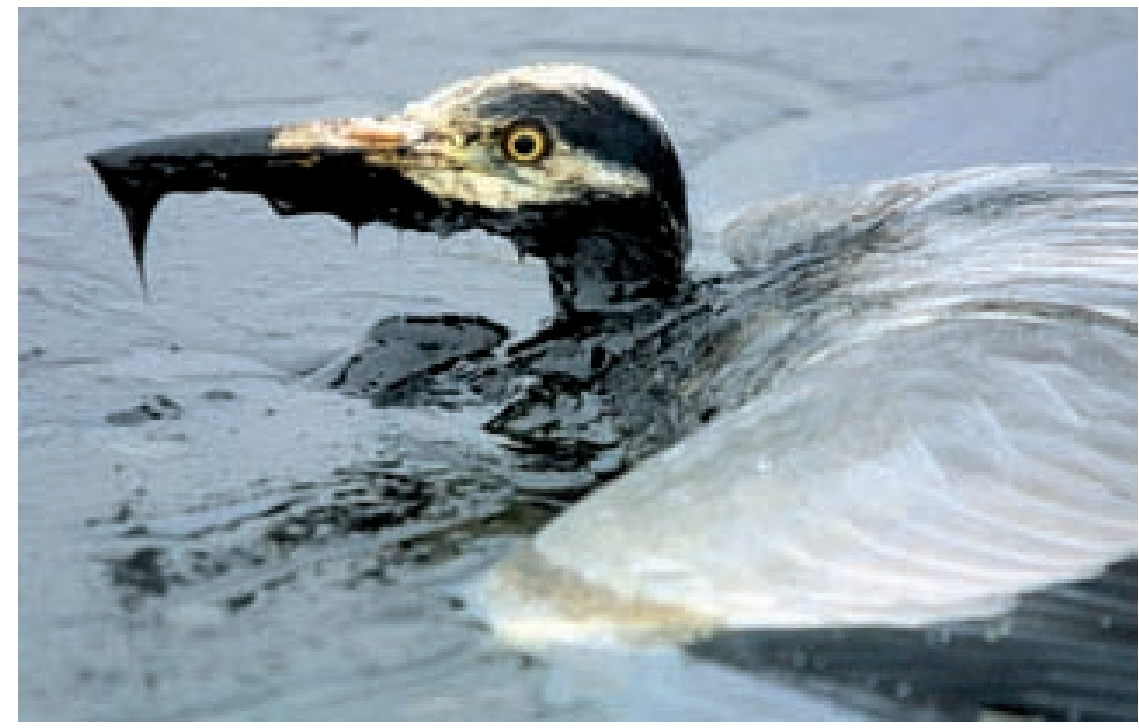

Árlega drepast margir vatnafuglar vegna olíumengunar. Hér má sjá gráhegra (Ardea cinerea) sem er ataður í olíu (ljósm.:Søren Steffen/Scanpix). 


\section{Samningurinn um heimsminjar}

\section{Samningur Menningarmálastofnunar Sameinuðu pjódanna (UNESCO) um vernd menningar- og náttúruarfleifðar heimsins}

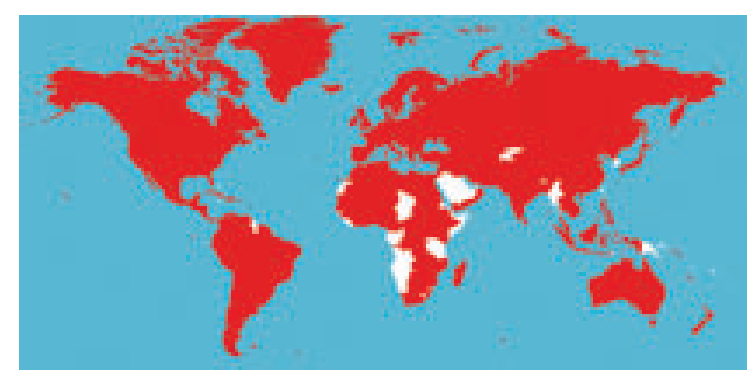

Adildarríki Menningarmálastofnunar Sameinuðu pjódanna sampykktu árið 1972 samninginn um vernd menningar- og náttúruarfleifdar heimsins. Hvatinn ad honum var sú hætta ad náttúruleg svædi, fornminjar og menningarminjar færu forgörðum vegna mengunar, ágangs ferdamanna, styrjalda eða almennrar hrörnunar.

\section{Markmið}

Markmiðið með samningnum um heimsminjar er fyrst og fremst ad tilgreina menningar- og náttúruminjar sem hafa gildi fyrir allt mannkyn og varðveita pær.

Etlunin er à beina athyglinni frekar ad menningar- og náttúruarfleifo heimsins og sjá til pess að adildarríkin setji í löggjöf sína ákvædi sem tryggja vernd náttúru- og menningarminjanna. Markmiðið er enn fremur ad koma á árangursríku og alpjódlegu samstarfi um vernd pessara minja í págu komandi kynslóda.

\section{Skilgreining}

Skilgreining Menningarmálastofnunar Sameinuðu pjódanna á náttúru- og menningararfleifð er mjög víd. Skilgreiningin tekur m.a. til sögufrægra bygginga, náttúrufyrirbæra, sem hafa fagurfræðilegt, jarðfræðilegt eða vísindalegt gildi, og búsvæda plöntu- og dýrategunda sem eru í útrýmingarhættu.

Samkvæmt skilgreiningu Menningarmálastofnunar Sameinuðu pjódanna eru pessi verðmætu fyrirbæri ýmist náttúruleg, manngerd eða petta hvort tveggja í senn.

\section{Heimsminjaskráin}

Peir staðir sem eru tilgreindir sem menningar- og náttúruarfleifd eru teknir upp í heimsminjaskrá Menningarmálastofnunar Sameinudu pjódanna. Hvert land, sem hefur fullgilt samninginn, kemur sjálft med ábendingar um nýja staði fyrir heimsminjaskrána.

Heimsminjanefndin, sem í eru fulltrúar 21 adildarríkis, skulu sampykkja tillögur um stadi eða náttúruminjar sem tekin verða upp i skránni. Ádur en nýjar tillögur eru lagðar fyrir nefndina fara pær gegnum vídtækt matsferli á vegum faglegra, óopinberra stofnana. Alpjódanáttúrverndarstofnunin (IUCN) annast pað mat ef um er að ræða náttúruleg fyrirbæri en
Alpjódarádid um minnisvarda og sögustadi (ICOMOS) ef um menningarminjar er ad ræda. Matið á ad tryggja ad kröfur, sem gerðar eru í samningnum um gæði, afmörkun og stjórn minjanna eda svæðanna séu uppfylltar.

Pótt staður eda minjar komist á heimsminjaskrána tryggir pad eitt ekki vernd hans eəa peirra, en gengid er út frá pví ad̀ viðkomandi ríki skuldbindi sig til að̀ varðveita viðkomandi stað eða minjar til framtídar. Sjötta hvert ár skulu

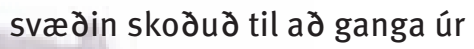
skugga um hvort verðmætin skerəist og hvort breyta purfi einhverju vardandi stjórnun.

Ef staður kemst á heimsminjaskrána er litið á pað sem mikla viðurkenn-

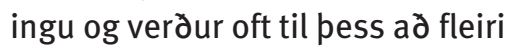
ferðamenn sækja hann heim en ádur. Aukinn fjöldi ferdamanna getur aukið tekjur en jafnframt geta áhrif vaxandi ferðamennsku verid neikvæð, t.d. vegna meiri ágangs en stadurinn polir. Sú krafa er gerd ad aðildarríkin séu sér meðvitud um pennan vanda ádur en pau tilnefna svædi sem pau vilja ad komist á heimsminjaskrána. 


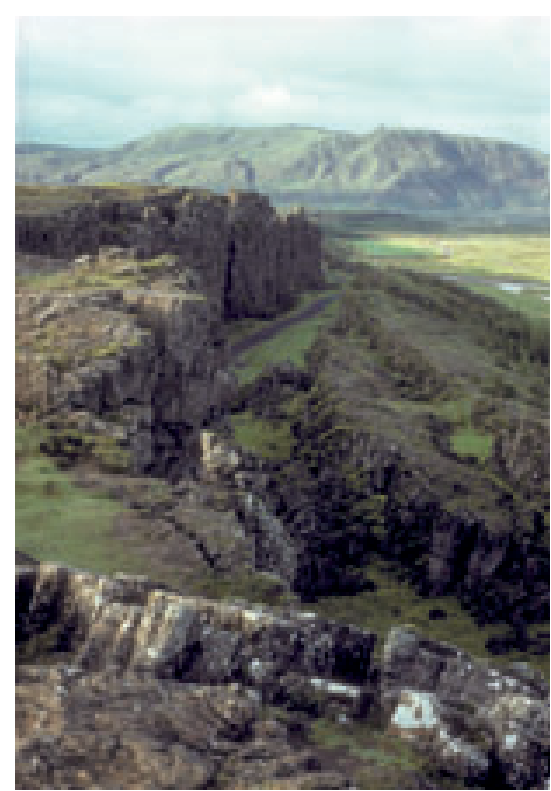

Pingvellir hafa verið settir á heimsminjaskrána, ad hluta vegna sögu stadarins og ad hluta vegna landslags og staðhátta. Alpingi Íslendinga var haldið á pingvöllum frá 930 til 1798 (ljósm.: Morten Lund Overgaard).

\section{Norrænt samstarf}

Norðurlöndin hafa komið upp

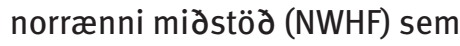
er ætlað að styrkja sameiginlegt átak til að vernda náttúru- og menningarminjar heimsins. Stofnun pessarar miðstöðvará að tryggja að Norðurlöndin virði ákvæði samningsins. Miðstöðin samræmir norræn átaksverkefni og starfar með Menningarmálastofnun Sameinudu pjódanna ad pví ad styðja pá heimshluta sem eiga tiltölulega fáa staði eða svæði á heimsminjaskránni.

Alls hafa 182 ríki, p.m.t. öll Norðurlöndin, gerst aðilar að samningnum.

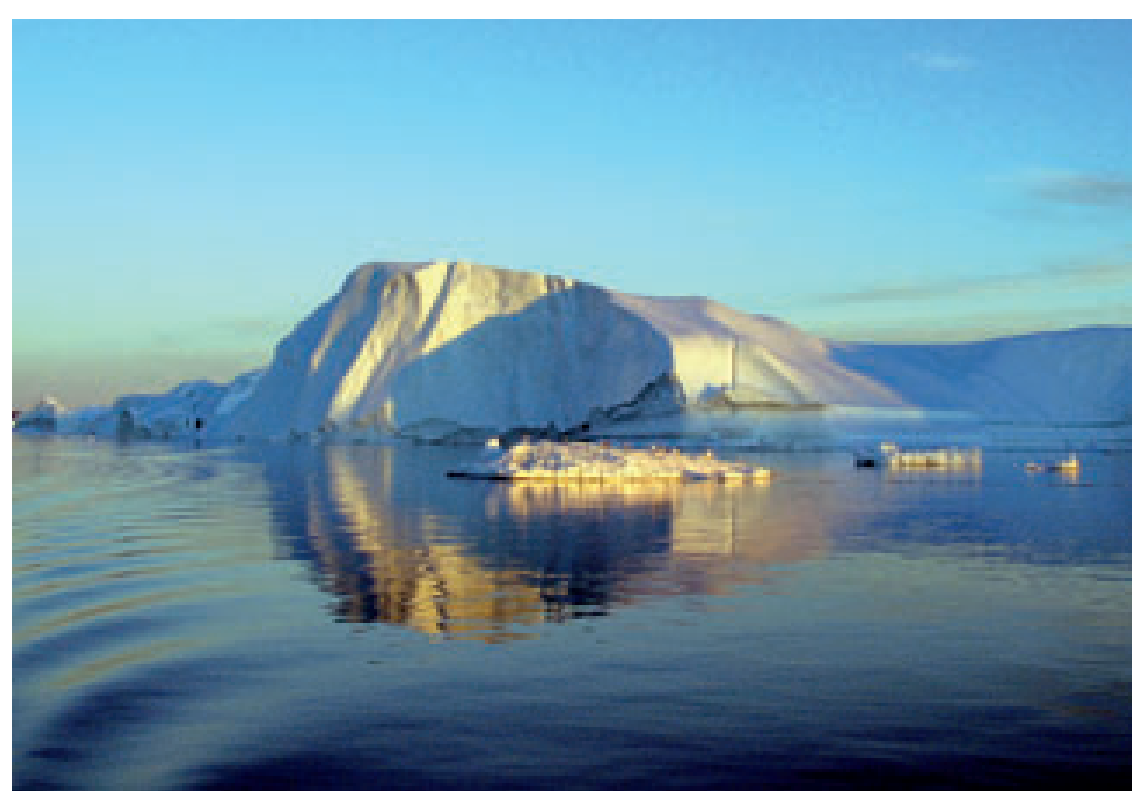

Enn er Ilulissat í ĺsfirði eini staðurinn á Grænlandi sem hefur komist á heimsminjaskrána. Á hverju ári skila skriðjöklarnir á svæдinu rúmlega $35 \mathrm{~km}^{3}$ af ís til sjávar. Rannsóknir á jöklunum hafa veitt vísindamönnum mikilvægar upplýsingar um loftslag jarðar eftir sí̉ustu ísöld (ljósm.: Slim Allagui/Scanpix).

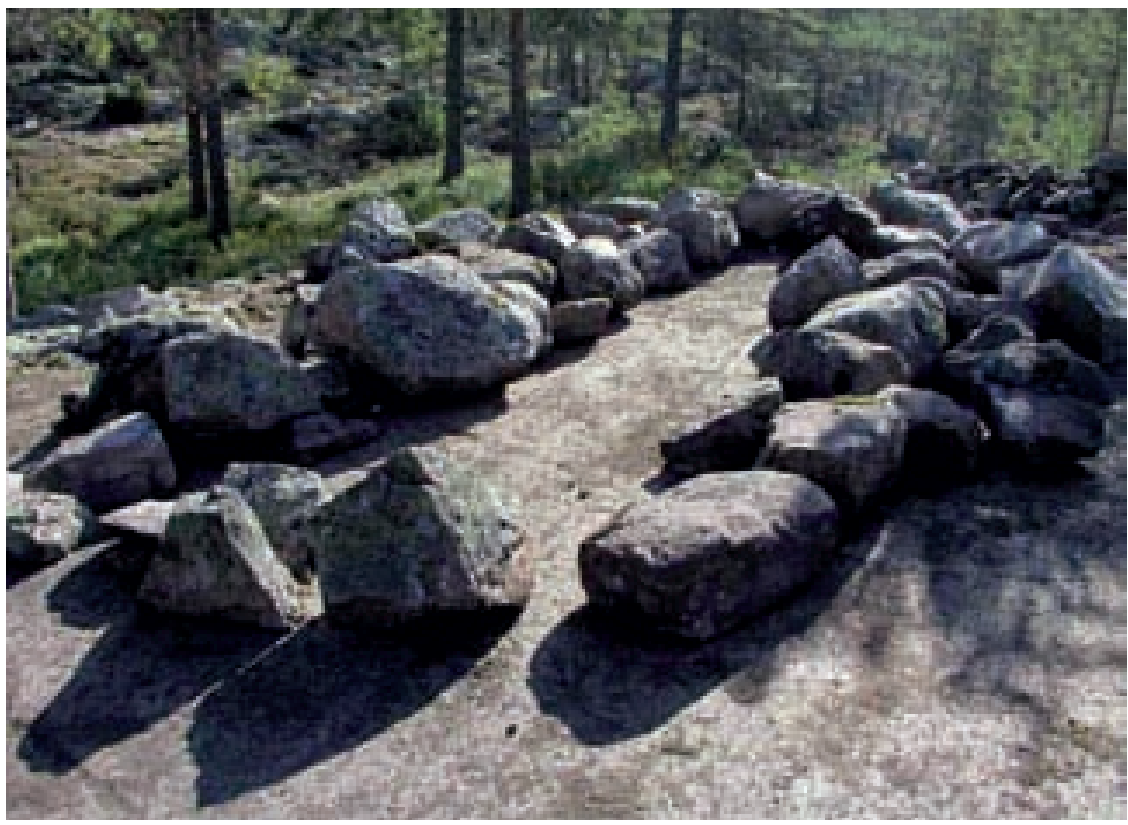

Sammallahdenmäki-haugarnir í Finnlandi eru frá bronsöld og eru á heimsminjaskránni. pessir haugar gefa einstaka mynd af samfélagi og trúarlífi fólks i Norður-Evrópu fyrir rúmum 3000 árum (ljósm.: Teija Tiitinen). 


\section{Evrópski landslagssamningurinn}

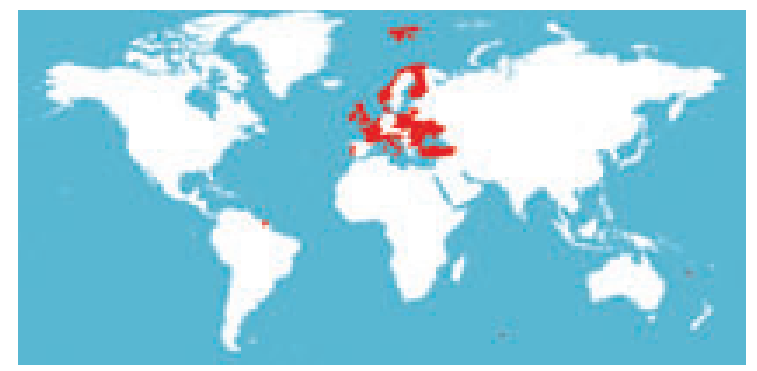

Landslag verkar á vitund fólks og endurspeglar fjölbreytileikann í sameiginlegri menningar- og náttúruarfleifð. Landslagið er víða algerlega náttúrulegt en í mörgum tilvikum er bad afrakstur af samspili náttúru og mannsins. Allar landslagsgerðir hafa mikið gildi fyrir velferð okkar og hagsæld. Landslagið breytist jafnfram án afláts vegna breytinga í pjóðfélaginu, t.d. í landbúnaði, iðnaði, landskipulagi og ferðapjónustu.

\section{Markmið}

Samningnum er ætlað aə tryggja ad íbúar Evrópu megi ávallt njóta fagurs landslags. Honum er ætlad að stuðla að vernd og gódri stjórn í tengslum vid landslag og hann á ad nýtast til að endurmóta landslag sem hefur verid spillt. Samningurinn skal enn fremur skapa grundvöll fyrir evrópskt samstarf um landslag.

\section{Hvad er landslag?}

Í samningnum er skilgreiningin á landslagi ví̉. Hún tekur bæði til landslags i i péttbýli og í landbúnadarhéruðum og til garða og náttúrulegra svæða - pað er að segja til allra landslagsgerda, án tillits til ástands eða gæða.

\section{Aukinn skilningur á landslagi}

Í pví skyni ad auka skilning fólks á gildi pess ad vernda landslag eru aðildarríkin skuldbundin til pess ad auka vitund manna á pví gildi sem landslag hefur fyrir velferd okkar og sjálfsvitund.

\section{Landslagsstefna}

Hvert aðildarríki ber sjálft pá ábyrgð að vernda landslag, stjórna pví og skipuleggja. Ríkin eru skuldbundin til ad meta landslag heima fyrir og pá pætti sem hafa áhrif á pad. Á grundvelli pessa mats skulu ríkin setja gæðamarkmið varðandi landslag. Íbúar og yfirvöld skulu eiga pess kost að taka pátt í ad setja gæðamarkmiðin og geta haft áhrif pegar ákvarðanir eru teknar sem hafa bein eða óbein áhrif á próun landslags.

\section{Alpjódlegt samstarf Aəildarríkjunum er skylt að starfa með öərum ríkjum og pvert yfir landamæri til aə leggja fram og hrinda i framkvæmd áætlunum um landslag, í sameiningu ef nauðsyn krefur.}

\section{Stjórn}

Landslagssamningurinn er undir stjórn nefndar Evrópurádsins um menningarminjar (CDPAT) og nefndar um líffræðilega fjölbreytni (CO-DBP).

Nú hafa 20 ríki fullgilt samninginn, m.a. Danmörk, Noregur og Finnland. 


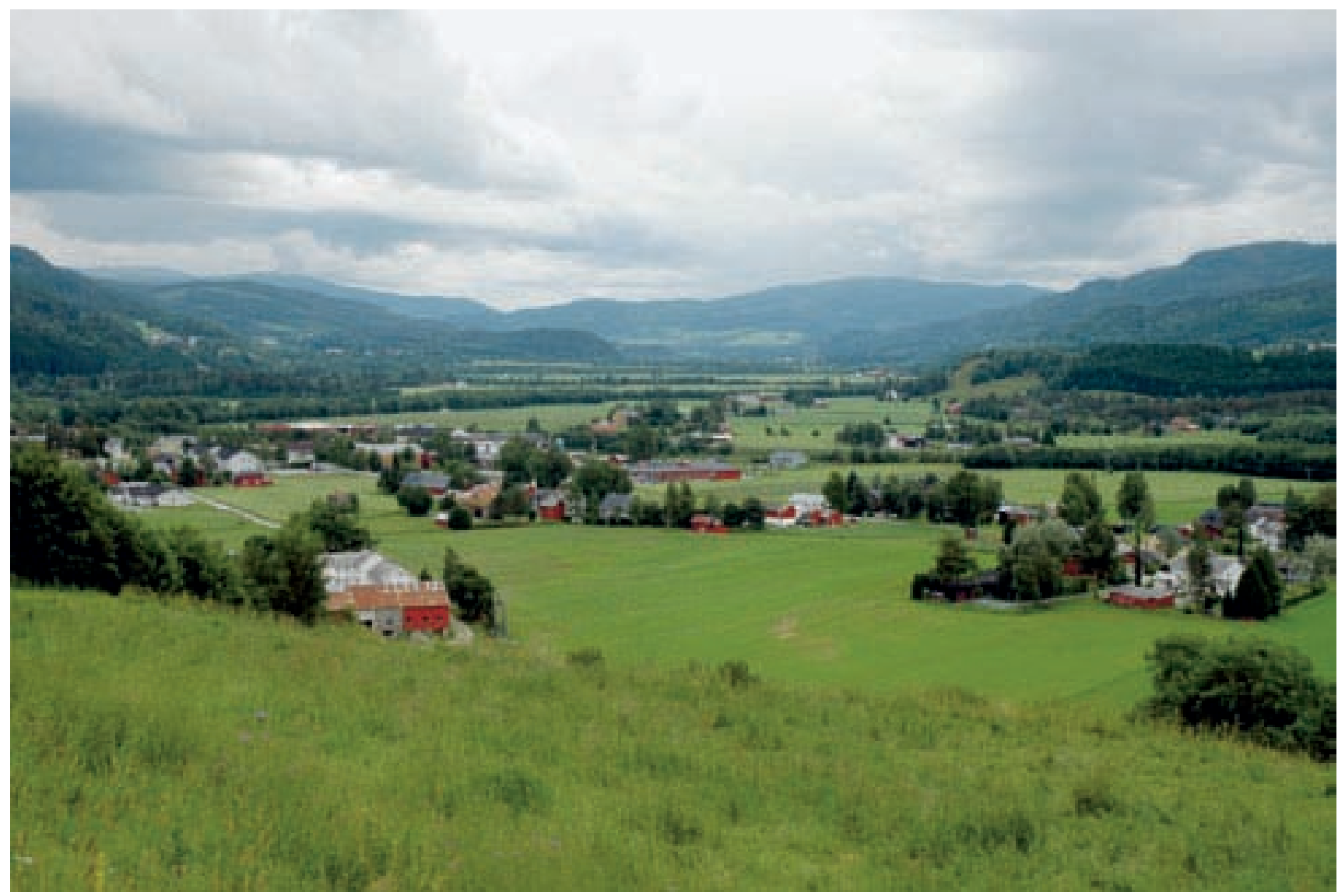

Í samningnum er landslag skilgreint sem svæði með einkenni og yfirbragð sem skapast hefur við náttúruleg skilyrði og/eða samspil náttúrulegra skilyrda og umsvifa mannsins (Orkdal, Noregur) (ljósm.: Carsten Brandt).

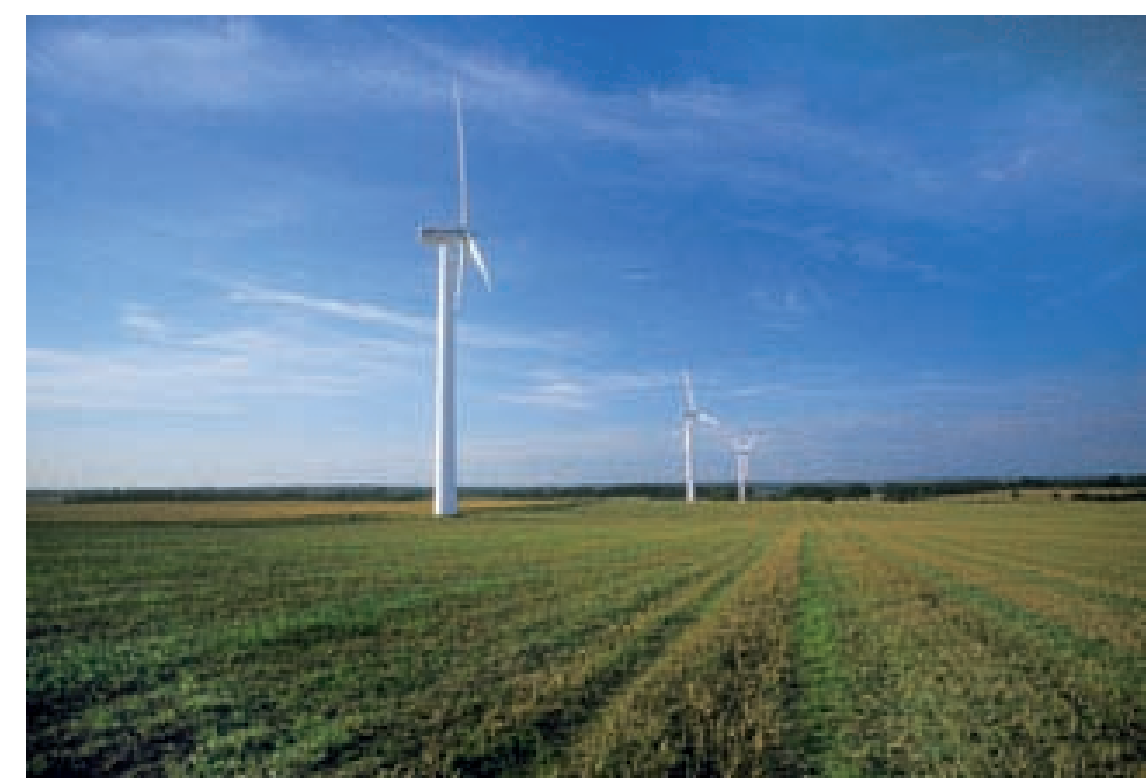

Landslagssamningurinn kveðu á um vernd margbreytilegra landslagsgerða og tekur til hvers kyns landslags. Ákvæði hans um vernd ná bæði yfir ræktað land og land sem er ósnortid af umsvifum mannsins (ljósm.: Stig Bachmann Nielsen/Naturplan). 


\title{
Granada-samningurinn
}

\author{
Samningurinn um varðveislu evrópskrar
}

\author{
byggingararfleifəar
}

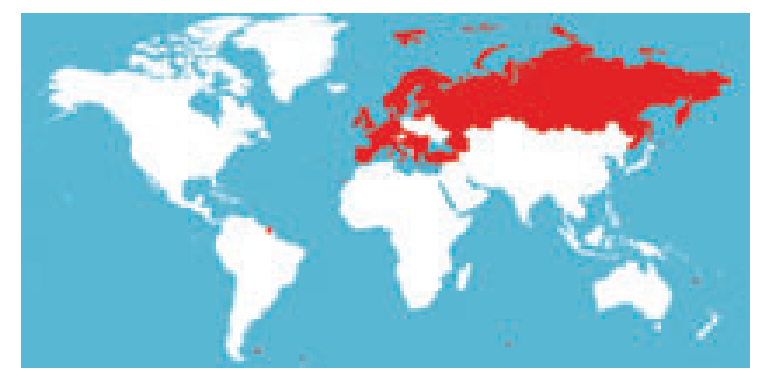

Byggingararfleifa Evrópu er einstaklega audug og fjölbreytileg. I byggingarlistinni varðveitist mynd af fortía og nútíd álfunnar. Hún er hluti af sameiginlegri sögu og samkennd íbúanna og er mikilvæg forsenda lífsgæða og pess að geta skynjad og notid.

\section{Markmid}

Markmiðið meд Granada-samning-

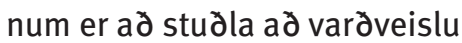
evrópskrar byggingarlistar og ad styrkja samstarf Evrópupjóda um petta verkefni.

\section{Byggingararfleifo}

Byggingararfleifəin er m.a. byggingar og minnisvardar sem fela í sér sögulegt, fornminjafræðilegt eða listrænt gildi. Hún getur enn fremur verið fólgin í svæðum, sem eru að hluta byggð og sköpuð af samspili manns og náttúru, eda í svæðum sem eru hluti peirrar sögulegu heildar sem byggingarnar og minnisvardarnir eru hluti af.

\section{Kröfur sem gerðar eru til aðildarríkjanna}

Granada-samningurinn skuldbindur aðildarríkin til að setja markmið um varðveislu bygginga og minnisvarða sem hafa byggingarlistarfræðilegt gildi. Markmiðin skulu höfð til hliðsjónar við skipulagningu péttbýlis og dreifbýlis og vera grundvöllur friðunar og endurgerðar hluta sem hafa byggingarlistarfrædilegt gildi.

Ríkin eru enn fremur skuldbundin til pess ad upplýsa pegna sína um gildi peirra sögulegu eða listrænu mannvirkja og minnisvarda í pví skyni ad auka áhugann á pví ad varðveita pessa hluti. Auk pess skulu adildarríkin efla samstarf sín á milli við varðveislu pessara byggingarlistarfræðilegu verðmæta.

\section{Frialýsing}

Fridlýsing er mikilvæg aðferð til pess að ná megi markmiðum samningsins. Fridlýsing getur hvort sem er gerst med vilja eigandans eða setji hann sig upp á móti henni - med eignarnámi. Yfirvöld í adildarríkjunum skulu einnig eiga pess kost ad leggja pá skyldu á herdar eigendum à viðhalda friðlýstri eign og að geta veitt styrki til að hrinda verkefnum tengdum varðveislu í framkvæmd.

\section{Menntun fagfólks}

Adildarríkin skulu samkvæmt samningnum sjá til pess à arkitektar, skipuleggjendur borga og bæja, handverksmenn og annad fagfólk afli sér menntunar og geti stadid

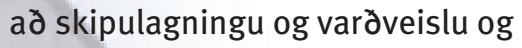
endurgerð peirra mannvirkja sem hafa byggingarlistarfræðilegt gildi.

\section{Framkvæmd samningsins}

Evrópurádid hefur sett á laggirnar nefnd, stýrinefnd um byggingararfleifə (CDPAT), sem ber ábyrgdá framkvæmd Granada-samningsins. Nefndin skal einnig leggja fram tillögur um hvernig megi bæta beitingu ákvæda samningsins og um breytingar á efni samningsins.

\section{Adildarríki}

Öll Norðurlönd, að Íslandi undanskildu, eru aðilar aə̀ samningnum. Adild Danmerkur tekur hvorki til Færeyja né Grænlands. 


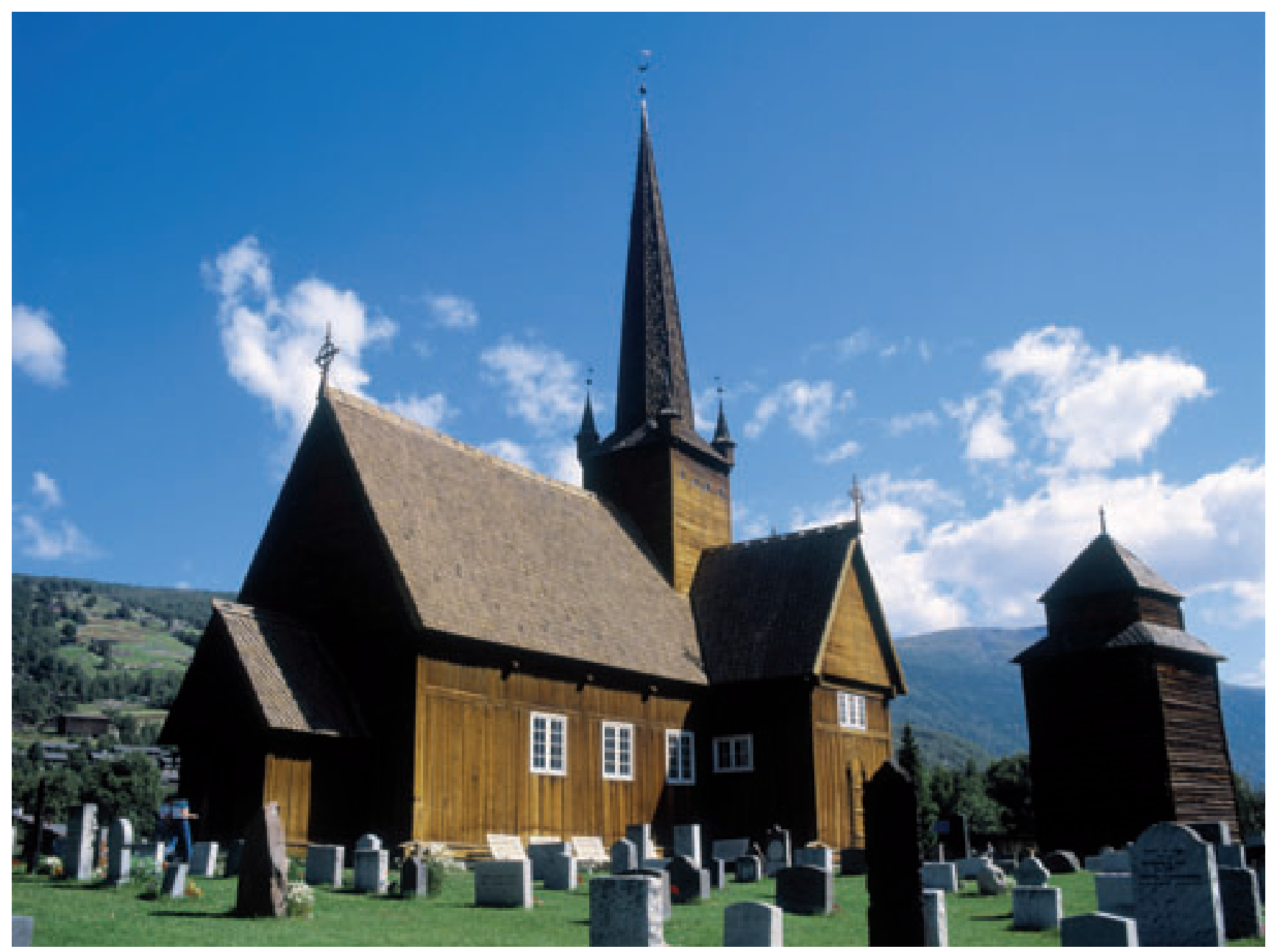

Granada-samningurinn er um vernd evrópskrar byggingararfleifaar, nýrrar og gamallar. Norsku stafkirkjurnar, t.d. stafkirkjan í Vågåmo, eru dæmi um gamla byggingarlist (ljósm.: Jan Djenner/Scanpix).

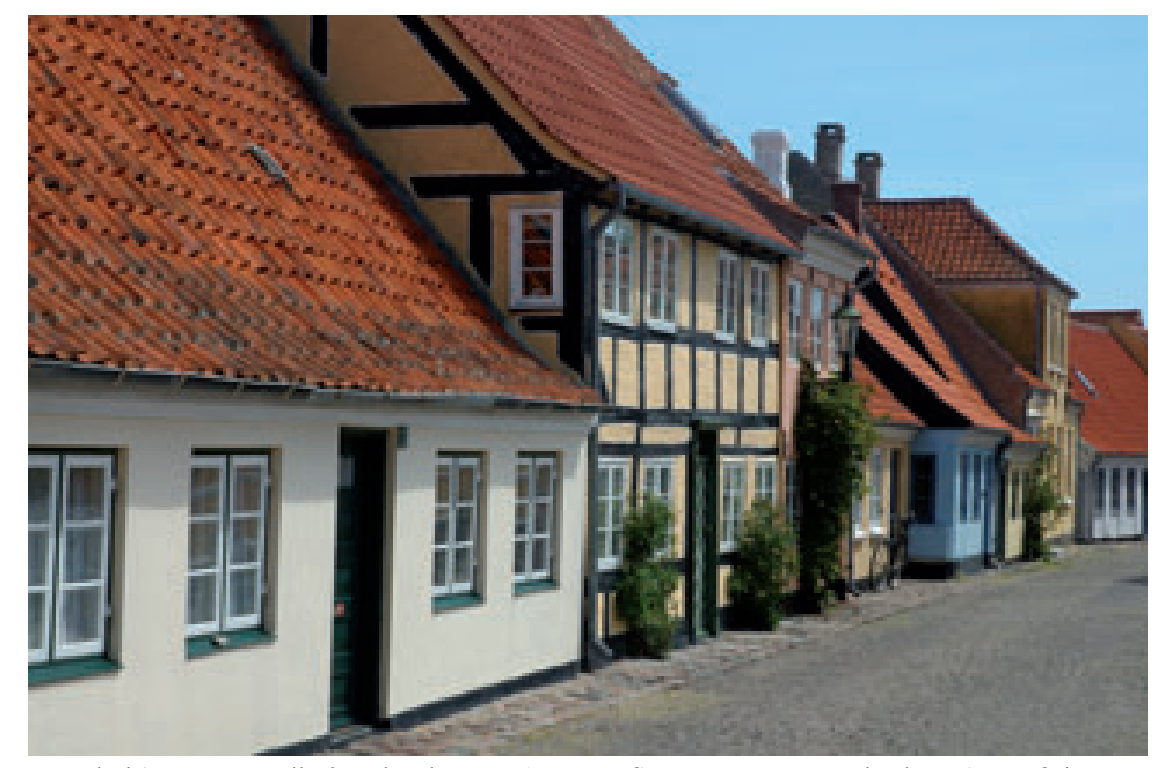

Arøskøbing er gamall, danskur kaupstaður. Par finnast um 40 gamlar byggingar frá 18. öld. Pær hafa nú verið friðlýstar (ljósm.: Stig Bachmann Nielsen/Naturplan).

www.conventions.coe.int CETS No.: 121 


\section{Möltusamningurinn}

\section{Samningur Evrópurádsins um vernd fornleifaarfsins}

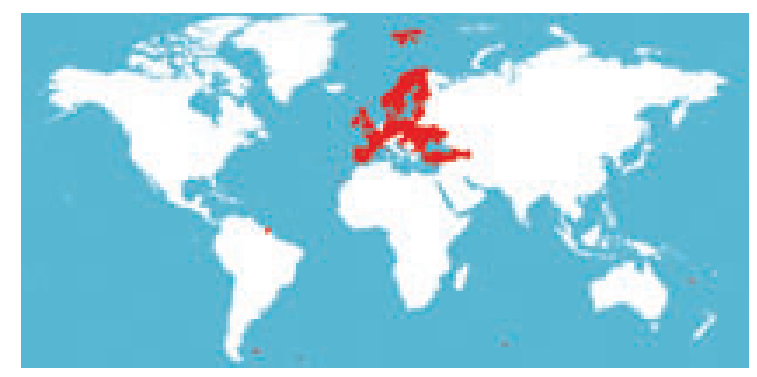

Möltusamningurinn var sampykktur í Valletta, höfuðstað Möltu, árið 1992. Samningurinn var gerdur vegna pess að talið var nauðsynlegt à tryggja vernd fornminja sem hluta menningararfsins á markvissari hátt en gert hafði verið ádur. Menningararfurinn tekur m.a. til mannvirkja, bygginga, landslagsheilda og hluta sem eru minjar fyrri tíma, segja sögu mannkyns og eru minni fyrri alda.

\section{Markmiz}

Markmiðið með samningnum er ad hlúa ad fornleifaarfinum pví ad pessi hluti menningararfsins er uppspretta og minni samevrópskrar sögu og tæki til vísindalegra og sagnfrædilegra rannsókna. Allar minjar fyrri tíma teljast hluti fornleifaarfsins ef:

1. varðveisla og rannsókn á beim studlar ad pví ad varpa ljósi á sögu mannkyns og tengslum pess við menningarumhverfið,

2. fundur peirra og uppgröftur eða adrar rannsóknaradferðir varpa skýru ljósi á vitneskju um menn fyrri tíma og umhverfi peirra og

3. pær eru á yfirrádasvædi aðildarlandanna.
Til ad ná markmiðunum, sem eru sett með samningnum, skulu aðildarríkin skrá fundarstaði fornleifa og fornminjar, tryggja ad unnt sé að friðlýsa eða kaupa svæði sem hafa mikla pýdingu vegna fornleifa og festa í lög pá skyldu að tilkynna skuli opinberum yfirvöldum um fund fornleifa. Ríkin skulu taka tillit til fornleifafræðilegra verðmæta í tengslum við skipulag og framkvæmdir við byggingar og önnur mannvirki. Ríkin eru einnig skuldbundin til pess að stöðva ólöglegan uppgröft og til að starfa með öðrum ríkjum, meðal annars til að koma í veg fyrir ólöglegan útflutning fornminja. Yfirvöldin skulu jafnframt eiga pess kost ad veita fjárhagslegan stuðning til ad varðveita verðmætar fornminjar.

\section{Adgengi ad fornminjum og efling almenningsvitundar}

Í samningnum er kvediðá um ad íbúar adildarríkjanna skuli hafa aðgang að fjölbreyttum fundarstöðum fornleifa. Samkvæmt samningnum eru ríkin einnig skuldbundin til à upplýsa pegna sína um mikilvægi forminjanna fyrir samfélagið. Einnig má nota fræðslu til pess að efla vitund almennings um starfsemi sem getur eydilagt fornminjar og ummerki fyrri tídar.

\section{Framfylgd samningsins}

Evrópurádid hefur sett á laggirnar nefnd sérfræðinga - stýrinefnd um menningararf (CDPAT) - sem ber ábyrgd á ad Möltusamningnum verði framfylgt. Nefndin skal einnig leggja fram tillögur sem miða ad betri framkvæmd samningsins og um breytingar á efni samningsins.

\section{Adildarríki}

Alls hafa 39 ríki fullgilt samninginn, meðal annars Danmörk, Finnland, Noregur og Svípjód. Adild Danmerkur tekur hvorki til Færeyja né Grænlands. 


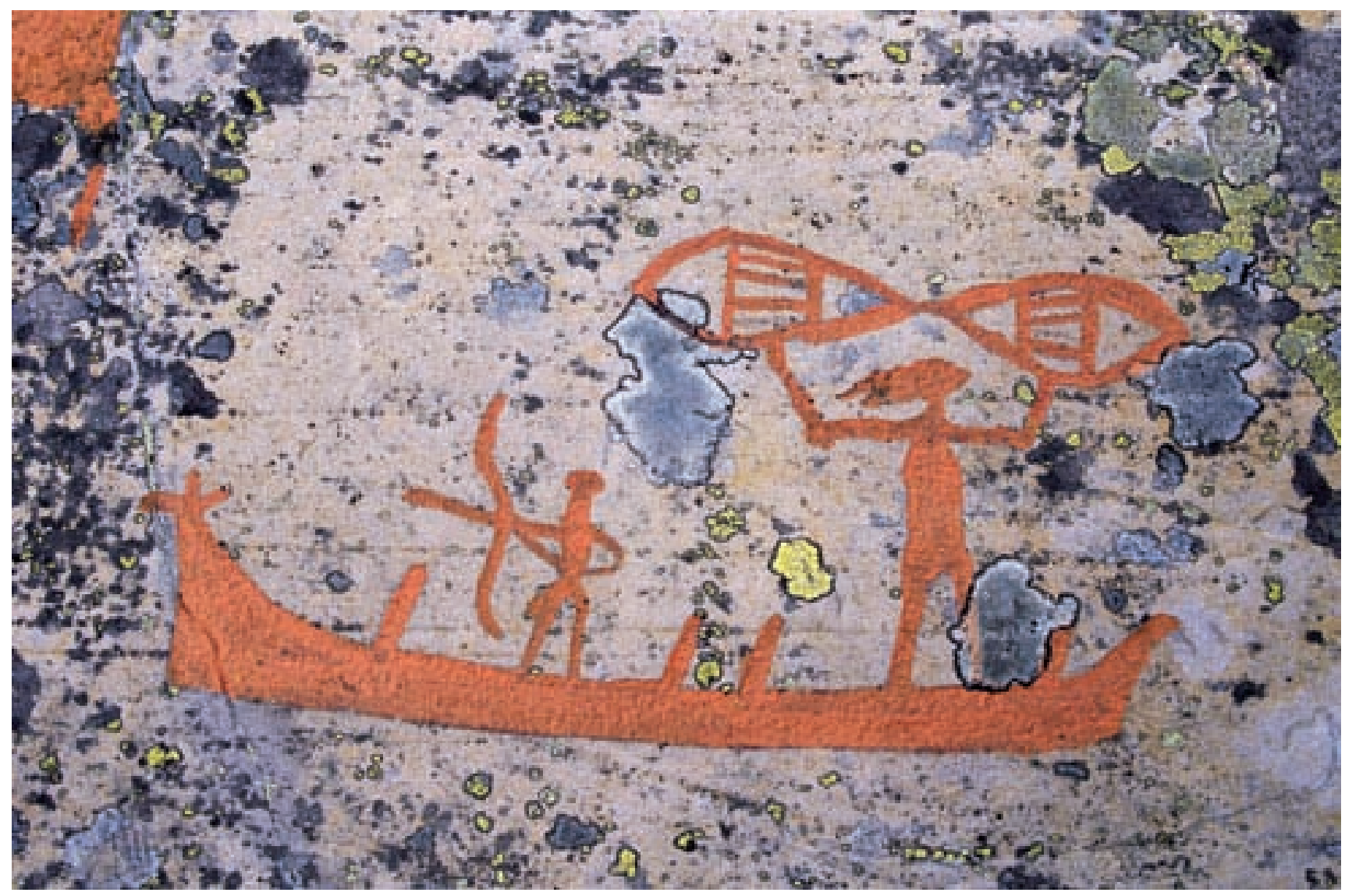

Hellaristurnar í Alta í Noregi eru meðal peirra fornminja sem Möltusamningurinn tekur til (ljósm.: Sven Halling/Scanpix).

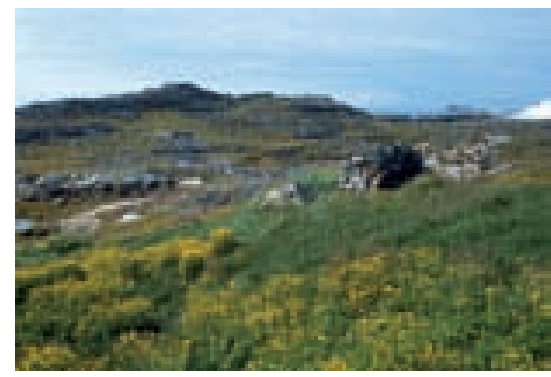

Byggð Inúíta á Akia-eyju felur í sér hluta af sögu grænlensku pjózarinnar (ljósm.: Anders Tvevad/Scanpix).

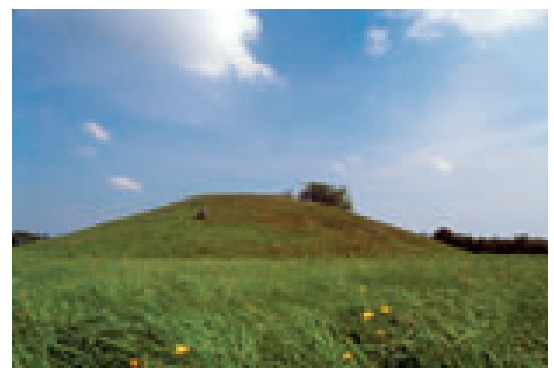

Í samningnum er kveðið á um að almenningur eigi aðgang að fjölbreyttu úrvali fornminja, medal annars aə fornum haugum (ljósm.: Stig Bachmann/Naturplan).

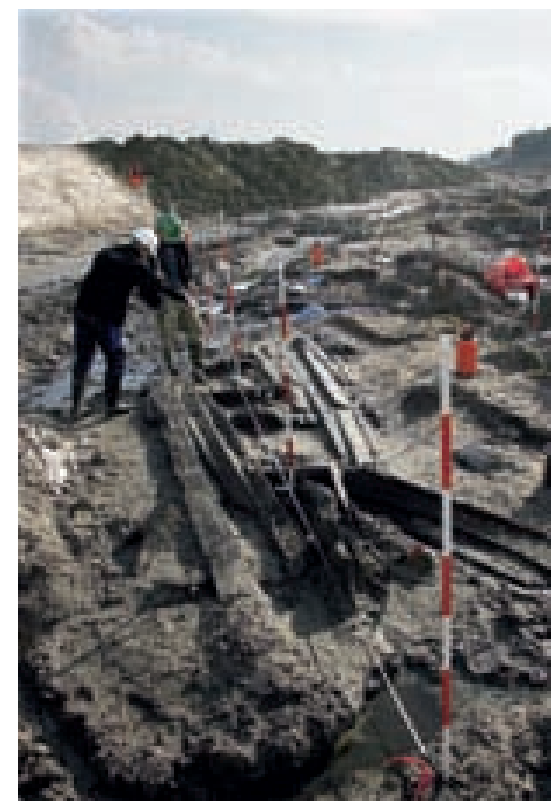

Möltusamningurinn tryggir að tillit er tekið til fornminja við smi̊i bygginga og aðra mannvirkjager (ljósm.: Jens Nørgaard Larsen/Scanpix). 


\title{
Árósasamningurinn
}

\author{
Samningur um aðgang að upplýsingum, pátttöku \\ almennings við töku ákvarðana og aðgangi að afgreiðslu
}

á kærum og dómsúrskurdum í umhverfismálum.

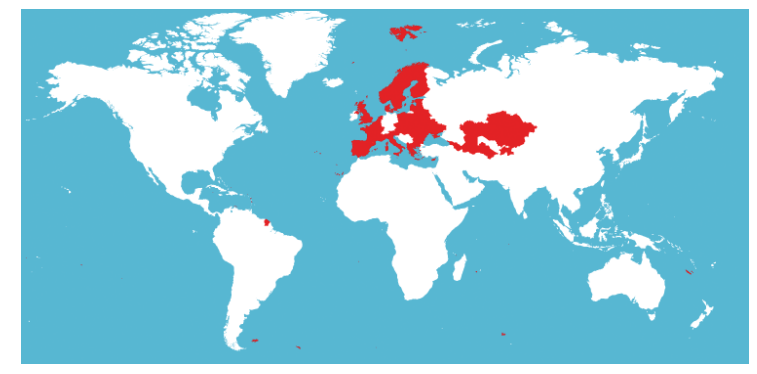

Árið 1998 komu umhverfisráðherrar yfir 50 landa saman til fundar í Árósum í Danmörku. Par sampykktu peir Árósasamninginn sem er ætlad à veita almenningi og stofnunum víðtækari áhrif á ákvarðanir sem eru teknar á sviði náttúru og umhverfis.

\section{Markmið}

Samningnum er ætlað að styrkja prjár lýðræðislegar meginreglur:

- Rétt til upplýsinga.

- Rétt almennings til ad taka pátt í ákvarðanatöku.

- Rétt til à bera fram kæru og fá úrskurð dómstóla eda nefndar.

Samningurinn gildir eingöngu um ákvarðanir sem hafa pýðingu fyrir náttúru og umhverfi.

\section{Réttur til upplýsinga}

Fyrsta meginreglan á à tryggja rétt almennings til upplýsinga í málum sem varða umhverfi og lífsskilyrði fólks. Réttur til upplýsinga er mikilvæg forsenda pess að almenningur geti tekið pátt í að móta pær ákvarðanir sem yfirvöld taka - og samkvæmt ákvæðum samningsins eiga allir pennan rétt óhád pjóderni, ríkisfangi og lögheimili.

\section{Réttur til ad taka pátt í ákvarðanatöku}

pad eitt að almenningur hafi aðgang að upplýsingum nægir ekki. Fólk á einnig að hafa áhrif á pær ákvarðanir sem eru teknar. Aəildarlöndin skuldbinda sig bví til aə hafa almenning með í rádum pegar taka skal ákvarðanir á sviði umhverfismála - til dæmis med pví að halda opna umræðufundi og borgarafundi. Almenningur skal meðal annars geta haft áhrif á ákvarðanir um ný fyrirtæki sem geta haft mengun í för med sér og um adra starfsemi sem hefur áhrif á umhverfid.

\section{Réttur til að bera fram kæru}

Samningurinn skal tryggja aə peir borgarar, pau fyrirtæki og pær stofnanir, sem verda fyrir áhrifum, hafi rétt til að bera fram kæru vegna ákvarðana um aðgang aə gögnum og um starfsemi sem getur haft umhverfisáhrif. İ samningnum eru enn fremur víðtæk ákvæði um að almenningur skuli geta höfдad mál eða borið fram kæru vegna ákvarðana sem falla undir löggjöf í tengslum við náttúru, umhverfi og skipulagsmál.
Hvert land um sig ákveður sjálft hverjir hafi i hverju tilviki nægilegra hagsmuna að gæta til að bera fram kæru.

Nú hafa 40 lönd fullgilt samninginn, meðal annarra Norðurlöndin, að undanskildum Ísland, Færeyjum og Grænlandi. 


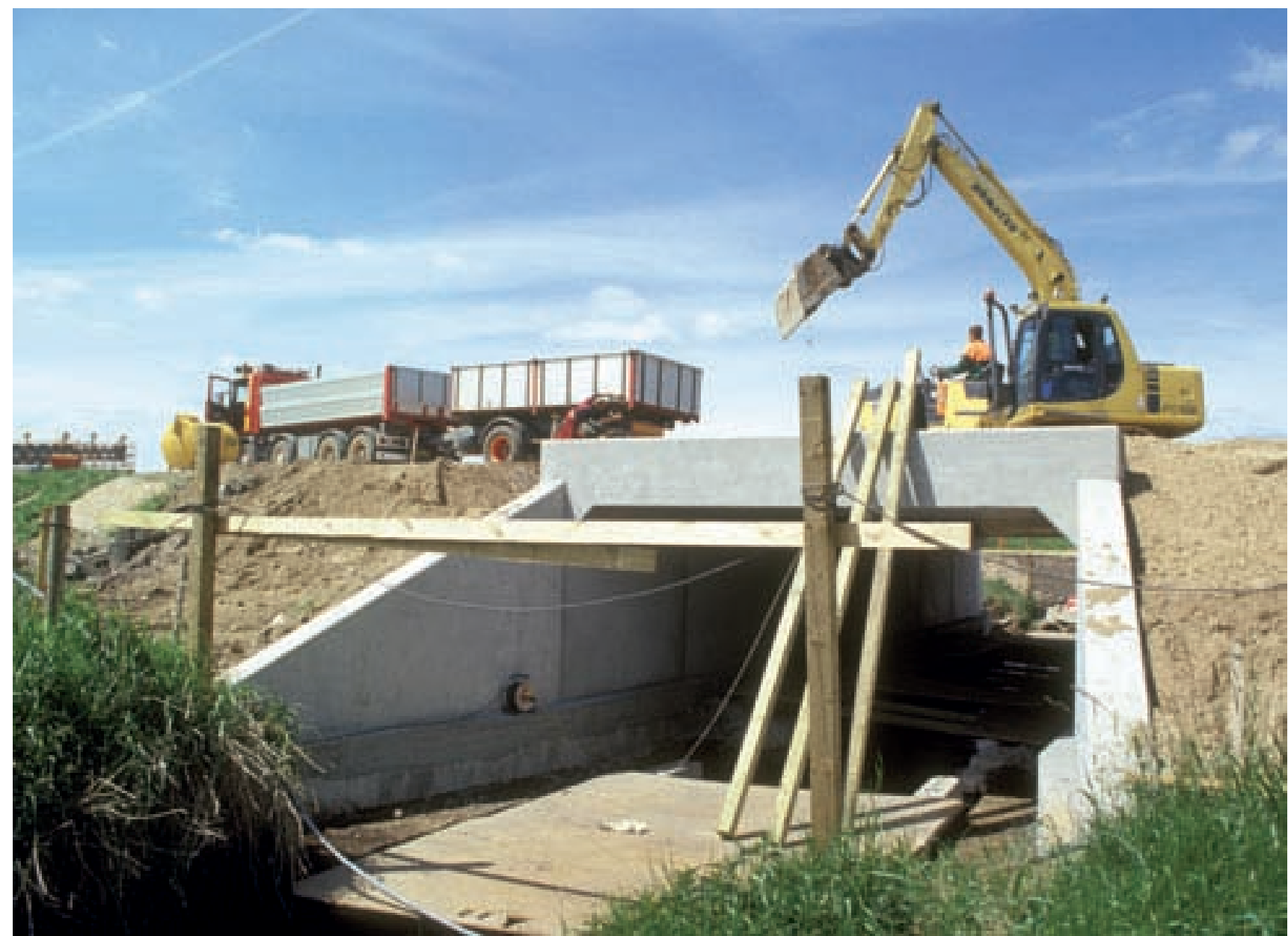

Árósasamningurinn tryggir almenningi rétt til að fá upplýsingar, taka pátt íákvarðanatöku og leggja fram kærur vegna framkvæmda sem geta haft óæskileg áhrifá umhverfið (ljósm.: Jens Muff Hansen/Naturplan).

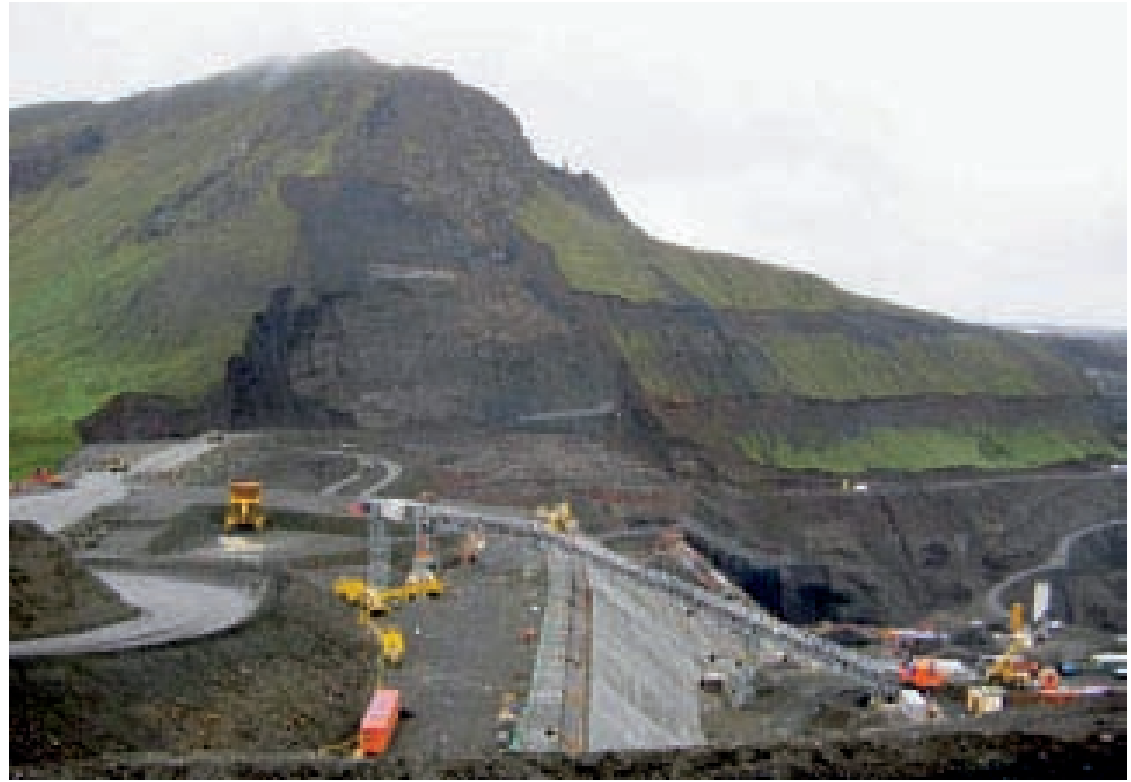

Rétturinn til að bera fram kærur snýr meðal annars að mannvirkjagerð, t.d. við gerð mannvirkja á bord vid Kárahnjúkavirkjun (ljósm.: Magnea I. Kristinsdóttir). 


\section{Alpjódaskrifstofur}

Samningurinn um líffræðilega fjölbreytni:

(The Convention on Biological Diversity)

Secretariat of the Convention on Biological Diversity

413 St-Jacques Street, 8th floor, Office 800

Montreal, Quebec, Canada, $\mathrm{H}_{2} \mathrm{Y}_{1} \mathrm{~N} 9$

Sími: +1-514-288-2220

Bréfasími: +1-514-288-6588

Netfang: secretariat@biodiv.org

Veffang: www.biodiv.org

\section{CITES-samningurinn:}

(The Convention on International Trade in Endangered Species of Wild Fauna and Flora)

UNEP/Regional Office for Europe - International Environment House

15, chemin des Anémones $\mathrm{CH}-1219$ - Châtelaine, Geneva

Switzerland

Sími: +41-22-917 8279

Bréfasími: +41-22-917 8024

Netfang: roe@unep.ch

Veffang: www.cites.org

\section{Ramsar-samningurinn:}

(The Convention on Wetlands of International Importance especially as Waterfowl Habitat)

Ramsar Convention Secretariat,

Rue Mauverney 28 ,

$\mathrm{CH}-1196$ Gland,

Switzerland

Sími: +41 22999 0170, +41229990169,

Netfang: ramsar@ramsar.org

Veffang: www.ramsar.org

\section{Bernarsamningurinn:}

(The Convention on the Conservation of European Wildlife and Natural Habitats)

Council of Europe

Avenue de l'Europe

67075 Strasbourg Cedex

Sími: +33(0)3 88412000

Veffang: www.conventions.coe.int

\section{Bonn-samningurinn:}

(The Convention on Migratory Species of Wild Animals)

UNEP / CMS Secretariat

United Nations Premises

Martin-Luther-King-Str. 8

D-53175 Bonn

Germany

Sími: (+49 228) $8152401 / 02$

Bréfasími: (+49 228) 8152449

Netfang: secretariat@cms.int

Veffang: www.cms.int

\section{Hvalveiðisamningurinn}

(The International Convention for the Regulation of Whaling)

The International Whaling Commission

The Red House,

135 Station Road,

Impington,

Cambridge,

Cambridgeshire CB4 9NP, UK.

Sími: +44 (o) 1223233971

Bréfasími: +44 (o) 1223232876

Netfang: secretariat@iwcoffice.org

Veffang: www.iwcoffice.org
Helsingfors-samningurinn:

(The Convention on the Protection of the Marine Environment of the Baltic Sea Area)

Helsinki Commission

(The Baltic Marine Environment Protection Commission)

Katajanokanlaituri 6 B

Fl-0016o Helsinki

Finland

Sími: +35896220220

Bréfasími: +358962202239

Veffang: www.helcom.fi

\section{OSPAR-samningurinn:}

(The Convention for the Protection of the Marine Environment of the North-East Atlantic)

OSPAR Secretariat

New Court

48 Carey Street

London WC2A 2JQ / UK

Sími: +44 (o) 2074305200

Bréfasími: +44 (o) 2074305225

Netfang: secretariat@ospar.org

Veffang: www.ospar.org

\section{Samningurinn um heimsminjar:}

(The Convention Concerning the Protection of the World Cultural and Natural Heritage)

The World Heritage Centre UNESCO

7, place de Fontenoy

75352 Paris 07 SP, France

Sími : 33-1-45 681571

Bréfasími : 33-1-45 685570

Netfang:wh-info@unesco.org

Veffang: whc.unesco.org

Nordic World Heritage Foundation

Fridtjof Nansens Plass 4

0160 Oslo

Norway

Netfang: nwhf@nwhf.no

Veffang: www.nwhf.no

Evrópski landslagssamningurinn:

(The European Landscape Convention)

Granada-samningurinn:

(The Convention for the Protection of the Architectural Heritage of Europe)

Möltusamningurinn:

(The European Convention on the Protection of the Archaeological Heritage)

Council of Europe

Avenue de l'Europe

67075 Strasbourg Cedex

Sími: +33(0)3 88412000

Veffang: www.conventions.coe.int

\section{Árósasammingurinn:}

(The Convention on Access to Information, Public Participation in Decision-making and Access to Justice in Environmental

Matters)

Aarhus Convention Secretariat

United Nations Economic Commission for Europe

Environment and Land Management Division

Palais des Nations

1211 Geneva 10

Switzerland

Sími: + 41229174226 / 9171502

Bréfasími: + 41229070107

Netfang: public.participation@unece.org

Veffang: www.unece.org/env/pp 


\section{Danmörk}

Samningurinn um líffræðilega fjölbreytni CITES-samningurinn

Ramsar-samningurinn

Bernarsamningurinn

Bonn-samningurinn

Hvalveiðisamningurinn

Helsingfors-samningurinn

OSPAR-samningurinn

Samningurinn um heimsminjar

Evrópski landslagssamningurinn

Granada-samningurinn

Möltusamningurinn

Árósasamningurinn

\section{Færeyjar}

Samningurinn um líffræðilega fjölbreytni Ramsar-samningurinn

Bonn-samningurinn

Hvalveiðisamningurinn

OSPAR-samningurinn

\section{Finnland}

Samningurinn um líffræðilega fjölbreytni CITES-samningurinn

Ramsar-samningurinn

Samningurinn um heimsminjar

Evrópski landslagssamningurinn

Árósasamningurinn

\section{Ísland}

Samningurinn um líffræðilega fjölbreytni CITES-samningurinn

Ramsar-samningurinn

Bernarsamningurinn

Hvalveiðisamningurinn

OSPAR-samningurinn

Samningurinn um heimsminjar

Árósasamningurinn

\section{Noregur}

Samningurinn um líffræðilega fjölbreytni

CITES-samningurinn

Ramsar-samningurinn

Bernarsamningurinn

Bonn-samningurinn

Hvalveiðisamningurinn

OSPAR-samningurinn

Samningurinn um heimsminjar

Evrópski landslagssamningurinn

Granada-samningurinn

Möltusamningurinn

Árósasamningurinn

\section{Færeyjar}

Samningurinn um líffræðilega fjölbreytn Ramsar-samningurinn

Bonn-samningurinn

Hvalveiðisamningurinn

OSPAR-samningurinn

\section{Svipjód}

Samningurinn um líffræðilega fjölbreytni

CITES-samningurinn

Ramsar-samningurinn

Bernar samningurinn

Bonn-samningurinn

Helsingfors-samningurinn

OSPAR-samningurinn

Samningurinn um heimsminjar

Evrópski landslagssamningurinn

Granada-samningurinn

Möltu-samningurinn

Árósasamningurinn www.skovognatur.dk www.skovognatur.dk www.skovognatur.dk www.skovognatur.dk www.skovognatur.dk www.skovognatur.dk www.mst.dk

www.mst.dk

www.unesco.dk

www.skovognatur.dk

www.kuas.dk

www.kuas.dk

www.mst.dk

www.imr.fo

www.imr.fo

www.imr.fo

www.fisk.fo

www.imr.fo

www.ymparisto.fi

www.ymparisto.fi

www.ymparisto.fi

www.nba.fi/en/whf

www.ymparisto.fi

www.ymparisto.fi

www.umhverfisraduneyti.is

www.ust.is

www.ust.is

www.ni.is

www.sjararutvegsraduneyti.is

www.umhverfisraduneyti.is

www.menntamalaraduneyti.is

www.umhverfisraduneyti.is

www.miljo.no
www.miljo.no
www.miljo.no
www.miljo.no
www.miljo.no
www.miljo.no
www.miljo.no
www.miljo.no
www.miljo.no
www.miljo.no
www.miljo.no
www.miljo.no

www.imr.fo

www.imr.fo

www.imr.fo

www.fisk.fo

www.imr.fo

www.regeringen.se

www.sjv.se

www.naturvardsverket.se

www.naturvardsverket.se www.naturvardsverket.se www.naturvardsverket.se www.naturvardsverket.se www.unesco-sweden.org www.raa.se

www.raa.se

www.raa.se

www.naturvardsverket.se 



\section{norden}

\section{Norræna rádherranefndin}

Store Strandstræde 18

DK-1255 København K

www.norden.org

\section{Bjartari framtid}

13 alpjódasamningar um náttúru og menningarumhverfi

Norðurlöndin hafa lengi verið pátttakendur í alpjóðlegu samstarfi sem miðar að̀ pví að vernda náttúru- og menningararfleifð heimsins. I pessu samstarfi eru samningar mikilvæg tæki.

I pessum bæklingi eru kynntir 13 mikilvægustu samningarnir, en peir snerta Norðurlöndin mismikið og sum peirra hafa komið að pví að semja pá og koma peim á fót. Samningarnir eru:

- Samningurinn um líffrædilega fjölbreytni

- CITES-samningurinn

- Ramsar-samningurinn

- Bernarsamningurinn

- Bonn-samningurinn

- Hvalveiðisamningurinn

- Helsingfors-samningurinn

- OSPAR-samningurinn

- Samningurinn um heimsminjar

- Evrópski landslagssamningurinn

- Granada-samningurinn

- Möltusamningurinn

- Árósasamningurinn

Sögulegur bakgrunnur samninganna er rakinn stuttlega. Pá eru mikilvægustu ákvæði hvers samnings nefnd og mikilvægi peirra fyrir Norðurlöndin skýrð.

Í bæklingnum er einnig að finna yfirlit yfir pað hver Norðurlandanna hafa gerst aðilar að einstökum samningum og hvar finna megi frekari upplýsingar.

Markhópurinn er stjórnmálamenn, embættismenn, stjórnendur, kennarar, stofnanir, sem hagsmuna eiga að gæta, og aðrir sem hafa áhuga á náttúru- og menningararfleifð. 